\title{
Integrated Ladinian bio-chronostratigraphy and geochrononology of Monte San Giorgio (Southern Alps, Switzerland)
}

\author{
Rudolf Stockar • Peter O. Baumgartner • \\ Daniel Condon
}

Received: 18 November 2011/ Accepted: 14 March 2012/Published online: 15 May 2012

(C) Swiss Geological Society 2012

\begin{abstract}
New biostratigraphic data significantly improve the age assignment of the Ladinian succession of Monte San Giorgio (UNESCO World Heritage List site, Southern Alps, Switzerland), whose world-famous fossil marine vertebrate faunas are now dated to the substage and zone levels. High-resolution single-zircon $\mathrm{U}-\mathrm{Pb}$ dating was performed using ID-TIMS and chemical abrasion (CA) pre-treatment technique on volcanic ash layers intercalated in the biostratigraphically-defined intervals of the Meride Limestone. It yielded ages of $241.07 \pm 0.13 \mathrm{Ma}$ (Cava superiore beds, $P$. gredleri Zone), $240.63 \pm 0.13 \mathrm{Ma}$ (Cassina beds, $P$ gredleri/P. archelaus transition Zone) and $239.51 \pm 0.15 \mathrm{Ma}$ (Lower Kalkschieferzone, P. archelaus Zone). Our results suggest that the time interval including the vertebrate-bearing Middle Triassic section spans around $4 \mathrm{Myr}$ and is thus significantly shorter than so far assumed. The San Giorgio Dolomite and the Meride Limestone correlate with intervals of the Buchenstein Formation and the Wengen Formation in the reference section at Bagolino, where the Global boundary Stratotype Section and Point (GSSP) for the base of the Ladinian was defined. The new radio-isotopic ages of the Meride
\end{abstract}

Editorial Handling: Daniel Marty.

R. Stockar $(\bowtie)$. P. O. Baumgartner

Institut de Géologie et Paléontologie, Université de Lausanne,

Anthropole, 1015 Lausanne, Switzerland

e-mail: rudolf.stockar@ti.ch

R. Stockar

Museo Cantonale di Storia Naturale, Viale Cattaneo 4,

6900 Lugano, Switzerland

D. Condon

NERC Isotope Geosciences Laboratory, British Geological

Survey, Nottingham NG12 5GG, England, UK
Limestone are up to 2 Myr older than those published for the biostratigraphically-equivalent intervals at Bagolino but they are consistent with the recent re-dating of the underlying Besano Formation, also performed using the CA technique. Average sedimentation rates at Monte San Giorgio are by more than an order of magnitude higher compared to those assumed for the Buchenstein Formation, which formed under sediment-starved pelagic conditions, and reflect prevailing high subsidence and high carbonate mud supply from the adjoining Salvatore/Esino platforms. Finally, the high-resolution U-Pb ages allow a correlation of the vertebrate faunas of the Cava superiore/Cava inferiore beds with the marine vertebrate record of the Prosanto Formation (Upper Austroalpine), so far precluded by the poor biostratigraphic control of the latter.

Keywords Ladinian - Monte San Giorgio .

Meride Limestone - Buchenstein Formation .

Biostratigraphy · Geochronology $\cdot \mathrm{U}-\mathrm{Pb} \cdot$ Ash bed ·

Zircon

\section{Abbreviation}

MCSN Museo cantonale di storia naturale, Lugano, Switzerland

\section{Introduction}

The Middle Triassic succession of Monte San Giorgio (Southern Alps, Switzerland/Italy; Fig. 1) has been inscribed on the UNESCO World Heritage List because of its unique palaeontological value and it is, in particular, world-famous for the exceptionally well-preserved fossil fishes and marine reptiles. Although this section is a rich 


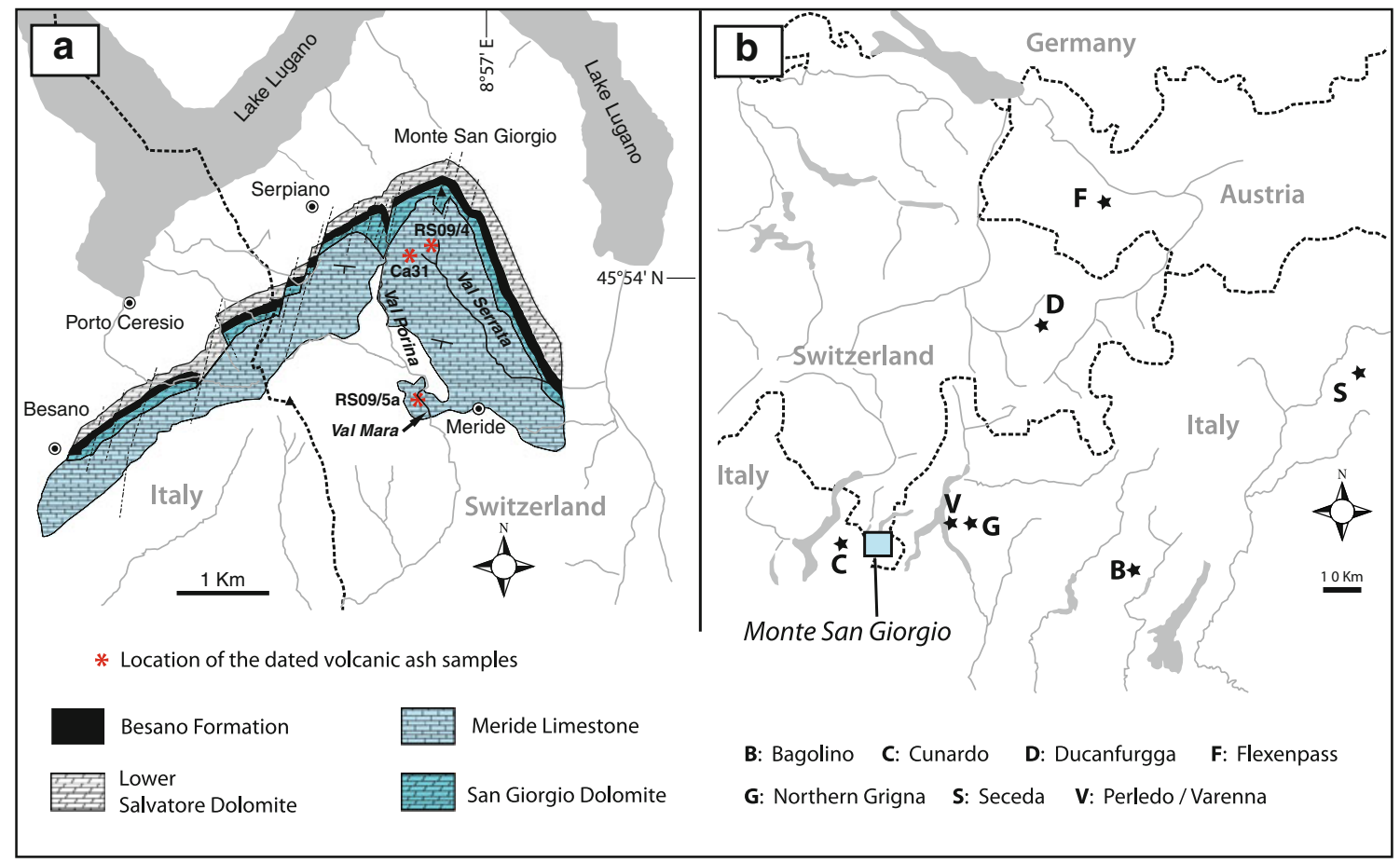

Fig. 1 a Simplified map of Monte San Giorgio showing the Middle Triassic carbonate succession and the location of the radio-isotopically dated samples. b Location of the Middle Triassic sections mentioned in the text

archive for the depositional environment of thanatocoenoses, which had (and still have) a major impact on the Middle Triassic palaeontology, the lack of sufficiently precise bio- and chronostratigraphic constraints still precludes a quantified assessment of both the basin and biota evolution. A unique exception is the upper Anisian-lowermost Ladinian Besano Formation, which provided a detailed age-diagnostic ammonoid and bivalve record and also yielded high-resolution radio-isotopic age data (Brack and Rieber 1993; Brack et al. 2005; Mundil et al. 2010). By contrast, the scarce age-diagnostic fossils so far reported from the overlying San Giorgio Dolomite and Meride Limestone formations provide only an uncomplete biostratigraphic framework while reliable radio-isotopic ages are not available at all. Consequently, conclusions on topics, which are crucial for this Lagerstätte, such as the assessment of evolutionary rates of its fossil vertebrate faunas, remain highly speculative.

$\mathrm{U}-\mathrm{Pb}$ isotopic dating using isotope dilution thermal ionization mass spectrometry (ID-TIMS) on single zircon grains from volcaniclastic layers intercalated within fossilbearing marine sediments provides at present the best means of directly cross-correlating biostratigraphic and geochronologic data. We apply this technique, coupled with the annealing/chemical abrasion (CA) pre-treatment procedure of Mattinson (2005), to the Ladinian sequence of Monte San Giorgio, which, in addition, has been constrained by new biostratigraphic data.
The main goals of this study are the following:

1. to re-define the biostratigraphic subdivisions of the Ladinian sequence at Monte San Giorgio and to correlate it with the reference section at Bagolino (northern Italy), bearing the GSSP for the base of Ladinian,

2. to resolve the age of the world-famous marine vertebrate faunas of the Meride Limestone to the substage and ammonoid zone level,

3. to correlate the fossil vertebrate faunas of the Meride Limestone with analogous faunas from the Upper Australpine realm which, although lacking a sufficient biostratigraphic control, are well-constrained by highresolution radio-isotopic dating,

4. to assess the average sedimentation rates of the basinal deposits composing the San Giorgio Dolomite and the Meride Limestone,

5. to provide new high-resolution radio-isotopic ages for the Ladinan Stage and to compare them with the available geochronologic data.

\section{Geological setting}

The Monte San Giorgio belongs to the Southern Alps, a fold-and-thrust belt extending over an area of $500 \mathrm{~km}$ (east to west) by $50-150 \mathrm{~km}$ (north to south) and bounded by the 
Insubric/Periadriatic Lineament to the north and west. To the east, the Southern Alps continue into the external Dinarides, whereas, to the south, the front of the SouthAlpine wedge is buried below the post-orogenic deposits of the Po Plain. In Middle Triassic times, the South-Alpine domain was situated on a passive continental margin open to the tropical western Neo-Tethys (e.g. Stampfli and Borel 2002), which was progressively submerged by a long-term transgression from the east. The marine ingression reached the eastern South-Alpine domain in the Late Permian and the westernmost (i.e. west of Lake Como) South-Alpine domain in late Anisian times. The palaeogeographic scenario was complicated by intensive Middle Triassic transtensive-transpressive tectonics, which resulted in a structural compartmentalization consisting in repeatedly uplifted and subsiding blocks. The geodynamic significance of these events is still debated and as puzzling as the character of the time-equivalent magmatism (see further below). However, even if unquestionably affecting the crustal structure of the Southern Alps, this tectonic activity does not seem to be related to the Late Triassic-Early Jurassic rifting of the Alpine Tethys and the opening of the Ligurian Ocean (Bertotti et al. 1993). The increasing differentiation of depositional environments occurring from late Anisian times onwards resulted in the development of a rapidly changing pattern of carbonate platforms, locally anoxic intraplatform basins and open-marine pelagic basins (Brack and Rieber 1993). Close to the base of the E. curionii Amm. Zone (earliest Ladinian), water depths reached maximum values (around $800 \mathrm{~m}$ ) in the Dolomites (eastern Southern Alps), while they were likely shallower towards the western Southern Alps (Brack and Rieber 1993; Brack et al. 2005).

\subsection{The Middle Triassic sequence of Monte San Giorgio}

The Monte San Giorgio basin is located at the western termination of the South-Alpine domain described above. This unique "remote" location resulted in a peculiar sedimentary succession and in at least temporarily severe dysoxic to anoxic bottom water conditions (Kuhn-Schnyder and Vonderschmitt 1954; Zorn 1971; Rieber 1973a; Bernasconi 1994; Furrer 1995, 2003; Röhl et al. 2001; Etter 2002; Stockar 2010). The Middle Triassic succession at Monte San Giorgio (Fig. 2) starts with fluvio-deltaic deposits dated to the late Anisian (Bellano Formation, Illyrian; Sommaruga et al. 1997), unconformably overlying a Lower Permian volcanic basement. The upper Anisian sediments testify to the progressive transgression of a shallow sea from the east and to the initiation of carbonate platform growth (Salvatore Dolomite/Esino Limestone; Zorn 1971) north of a land area buried today below the Po

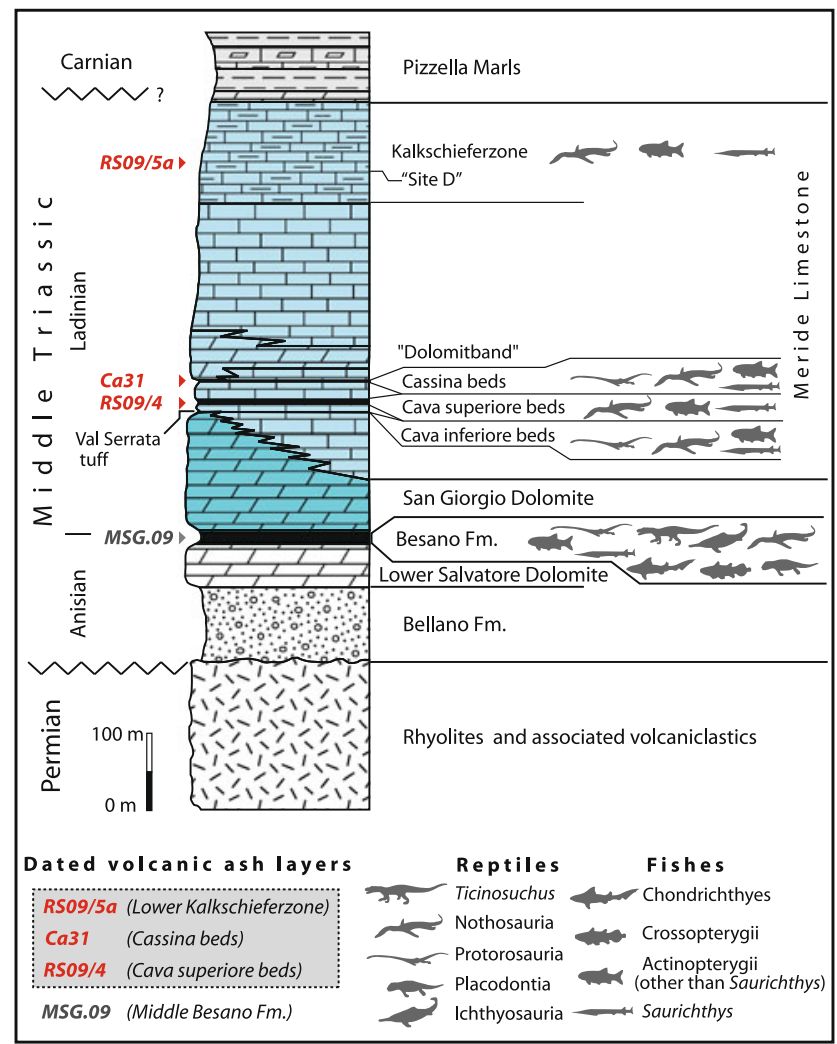

Fig. 2 Stratigraphic section of the Middle Triassic sediments in the Monte San Giorgio area with the main vertebrate-bearing levels (modified and updated from Furrer 1995). Radio-isotopically dated volcanic ash layers are indicated. RS09/4, RS09/5a and Ca31: this paper. MSG.09: Mundil et al. (1996, 2010)

plain (Picotti et al. 2007). Dolomitized microbial limestones, characterized by stromatolitic lamination, were deposited in a shallow subtidal to intertidal environment (Lower Salvatore Dolomite). While in the north and in the east shallow-water sedimentation continued, during the latest Anisian and Ladinian in the Monte San Giorgio area the formation of an intraplatform basin with restricted circulation resulted in the deposition of the Besano Formation, the San Giorgio Dolomite and the Meride Limestone (Bernasconi 1994; Furrer 1995, 2003). The Besano Formation ("Grenzbitumenzone"; Frauenfelder 1916) directly overlies the Lower Salvatore Dolomite and is composed of a $16 \mathrm{~m}$ thick alternation of black shales and laminated dolostones. Its uppermost part includes the Anisian/Ladinian boundary (=base of the E. curionii Amm. Zone; Brack and Rieber 1993; Brack et al. 2005). Most of the spectacular vertebrate fossils (reptiles and fishes) together with important index fossils including ammonoids and daonellid bivalves come from this formation (e.g. Rieber 1969, 1973b; Kuhn-Schnyder 1974; Bürgin et al. 1989). The Besano Formation grades upwards into the San Giorgio Dolomite and the Meride Limestone, all together constituting an around $600 \mathrm{~m}$ thick sequence. 
The base of the San Giorgio Dolomite is defined at layer 187 of the standard profile at locality Mirigioli (Site P. 902; Rieber 1973b; Bernasconi 1994) where the Besano Formation was excavated bed by bed between 1950 and 1968 and yielded exceptional vertebrate fossils (Kuhn-Schnyder 1974). The section is no longer accessible, but thickness and lithofacies are laterally consistent enough to allow a reliable correlation of single beds at different localities of the Monte San Giorgio area. The transition from the Besano Formation to the San Giorgio Dolomite is marked by the disappearance of black shales, by a reduction of laminated dolostones and by a major decrease in the organic matter content (Bernasconi 1994). Sections in Val Porina and Val Serrata (Fig. 1a) show that the San Giorgio Dolomite results from early and late diagenetic dolomitization, the latter cutting across stratification and affecting the original limestones in an irregular pattern up to a major volcaniclastic bed ("Val Serrata tuff") lying around $165 \mathrm{~m}$ above the base of this unit (Fig. 2).

The Lower Meride Limestone chiefly consists of wellbedded limestones. Most of the carbonate was likely derived from the adjacent highly productive Salvatore/Esino carbonate platforms providing a constant supply of carbonate mud to the basin. Three intervals (Cava inferiore beds, Cava superiore beds and Cassina beds), mainly consisting of finely laminated limestones with intercalated volcanic ash layers, are present in the upper part of the Lower Meride Limestone and yielded different vertebrate fossil assemblages (Peyer 1931; Sander 1989; Furrer 1995, 2003; Stockar 2010). The top of the Lower Meride Limestone is defined by a very irregular discontinuous dolomite horizon ("Dolomitband"; Frauenfelder 1916), averaging around $30 \mathrm{~m}$ in thickness (Wirz 1945; Furrer 1995). The overlying Upper Meride Limestone is a sequence of alternating wellbedded limestones and marlstones, mainly representing dilute lime mud turbidites. The uppermost part comprises the 120 m thick "Kalkschieferzone" (Senn 1924), made up of thin-bedded, mostly laminated, limestones and marlstones with peculiar faunas of fishes, reptiles, crustaceans and insects. It represents the latest stage of the intra-platform basin, recording strong seasonal variations of salinity and water level, which was progressively buried by an increasing input of siliciclastic material (Furrer 1995).

The east-west extension of the Monte San Giorgio basin is estimated to have been about $10 \mathrm{~km}$ or up to $20 \mathrm{~km}$ if it was located in the same basin as the Perledo-Varenna Formation outcropping to the east of Lake Como (Gianotti and Tannoia 1988; Bernasconi 1994). Basin depths are regarded as varying between 30 and $130 \mathrm{~m}$ (Monte San Giorgio basin; Zorn 1971; Rieber 1973a; Bernasconi 1994) and 160-260 m (Perledo-Varenna Formation; Gaetani et al. 1992). Further to the east, the depositional setting of the Perledo-Varenna Formation was, in turn, separated from the pelagic deposits of the "Buchenstein" facies by shallow-water barriers (Esino Platform, an equivalent to the Salvatore Platform in the lake Como region), only a few meters deep (Gaetani et al. 1992). Finally, as the Meride Limestone is considered to be the source rock of the Trecate-Villafortuna oil fields (Po Plain; Picotti et al. 2007), the intra-platform basin system probably extended southwards for over $60 \mathrm{~km}$.

For the compilation of the composite section illustrated in this paper, stratigraphic successions have been studied at the $\mathrm{cm}$-scale at the following localities (approximated Swiss National Coordinates refer to the centre of the sections): Val Porina (716'600/85'100), Valle della Cassina (717'150/84'950), Val Sceltrich $\left(717^{\prime} 000 / 84^{\prime} 400\right)$, Val Serrata $\left(717^{\prime} 850 / 84^{\prime} 150\right.$ and $\left.717^{\prime} 900 / 83^{\prime} 700\right)$ and Fontana Fredda-Val Mara $\left(717^{\prime} 050 / 83^{\prime} 350\right)$. The widespread occurrence of volcanic ash beds, sometimes associated with weathering-resistant silicified horizons, as well as the lateral persistence of bedding patterns allow an unambiguous correlation of the studied sections. A major unresolved uncertainty occurs at the base of the Kalkschieferzone (Val Mara; Fig. 1a), where a fault with unknown displacement precludes to observe the transition to the underlying part of the Upper Meride Limestone.

\subsection{The Middle Triassic volcanic ash layers} in the Southern Alps

Middle Triassic pelagic sediments containing zircon-bearing acidic volcaniclastic horizons, usually with a greenish colour, are widespread in the Southern Alps. Sedimentologic and petrographic features indicate an air-borne origin of the sand- to silt-sized particles of these so-called "Pietra Verde" layers, which Brack et al. (2005) suggested to have probably originated from eruption centres mainly located outside the present Southern Alps. Beyond the Southern Alps, comparable volcaniclastic layers occur in the Eastern Alps (e.g. Brühwiler et al. 2007; Furrer et al. 2008), in the Briançonnais unit of the Western Alps (Caby and Galli 1964) and further afield (e.g. Balaton Highland, Hungary; Pálfy et al. 2003). Current interpretations of this widespread volcanic activity are highly divergent but chiefly relate it to the evolution of the Maliac-Meliata Ocean to the east. According to these models, the volcanic episode could result from the extension associated with the opening of this ocean in a general strike-slip scenario or from the subduction of its young lithosphere (or of a segment of the Palaeo-Tethys) generating a volcanic arc on continental crust (see Bernoulli 2007 for a review).

Whatever the origin of the Middle Triassic volcanic episode, due to their lateral persistence these tephra layers proved ideal markers for precise correlations of sections up to $200 \mathrm{~km}$ apart (Brack and Rieber 1993; Brack and 
Muttoni 2000; Brühwiler et al. 2007). Moreover, starting in 1996 (Mundil et al. 1996), several of these horizons have been dated by $\mathrm{U}-\mathrm{Pb}$ single zircon techniques, allowing a geochronologic framework to be established.

In the reference section at Bagolino (eastern Lombardy, northern Italy), bearing the GSSP for the base of the Ladinian Stage (Brack et al. 2005), Pietra Verde layers occur throughout the Buchenstein Formation section but they are chiefly concentrated in three intervals (Fig. 3). Pietra Verde layers first appear in the upper part of the interval transitional from the pelagic Prezzo Limestone to the siliceous nodular limestones of the Buchenstein Formation and follow a first stack of beige weathering tuff beds ("Ta-tuffs"). Millimetre- to a few decimetre-thick greenish acidic ash beds concentrate at the 56-62, 68-76 and 82-92 m intervals, constituting the so-called Lower, Middle and Upper Pietra Verde respectively. At the top of the Upper Pietra Verde, a major change in sedimentation occurs which marks the abrupt switch to the siliciclastic Wengen Formation. Pietra Verde layers constitute a powerful tool to correlate Buchenstein-type sections across the Southern Alps (Brack and Rieber 1993; Brack and Muttoni 2000; Muttoni et al. 2004) and could be laterally safely traced as far as the Dolomites where, at Seceda, lies the principal auxiliary section for the GSSP.

At Monte San Giorgio, intercalations of volcanic ash layers occur throughout the upper Anisian-Ladinian section, i.e. from the Besano Formation to the Kalkschieferzone of the Upper Meride Limestone. Only in the uppermost part (Upper Kalkschieferzone) they are missing. Their lateral persistence makes them a reliable tool for bedby-bed correlations among partial sections. The ash layers are air-borne tuffs altered to bentonite, without any detrital admixture; at least the thicker ones show a distinct gradation with a sand-sized basal part. Bentonites are usually easily detectable in outcrop as they weather to an orange colour. Thickness usually ranges from less than one millimetre to few centimetres. In the reference profile of the Besano Formation (Rieber 1973b; Bernasconi 1994) 36 ash layers have been recognized, while in the overlying San Giorgio Dolomite and Meride Limestone over thirty ash layers, between a few millimetres to $50 \mathrm{~cm}$ thick, have been reported by Wirz (1945). Sub-mm yellowish bentonite seams, however, are very frequent in the Meride Limestone but they can be detected only on fresh bedding surfaces, as highlighted by bed-by-bed excavations (e.g. Stockar 2010). Somewhat different is the so-called "Val Serrata tuff" (Lower Meride Limestone), a tuffite with a carbonate cement representing one of the most reliable marker beds of the sequence. It consists of a lower and an upper bed, up to 4 and $3 \mathrm{~m}$ thick respectively, bracketing the $1.5-\mathrm{m}$-thick fossiliferous sequence informally called "Cava inferiore beds" (Sander 1989; Furrer 1999a). Composition of the

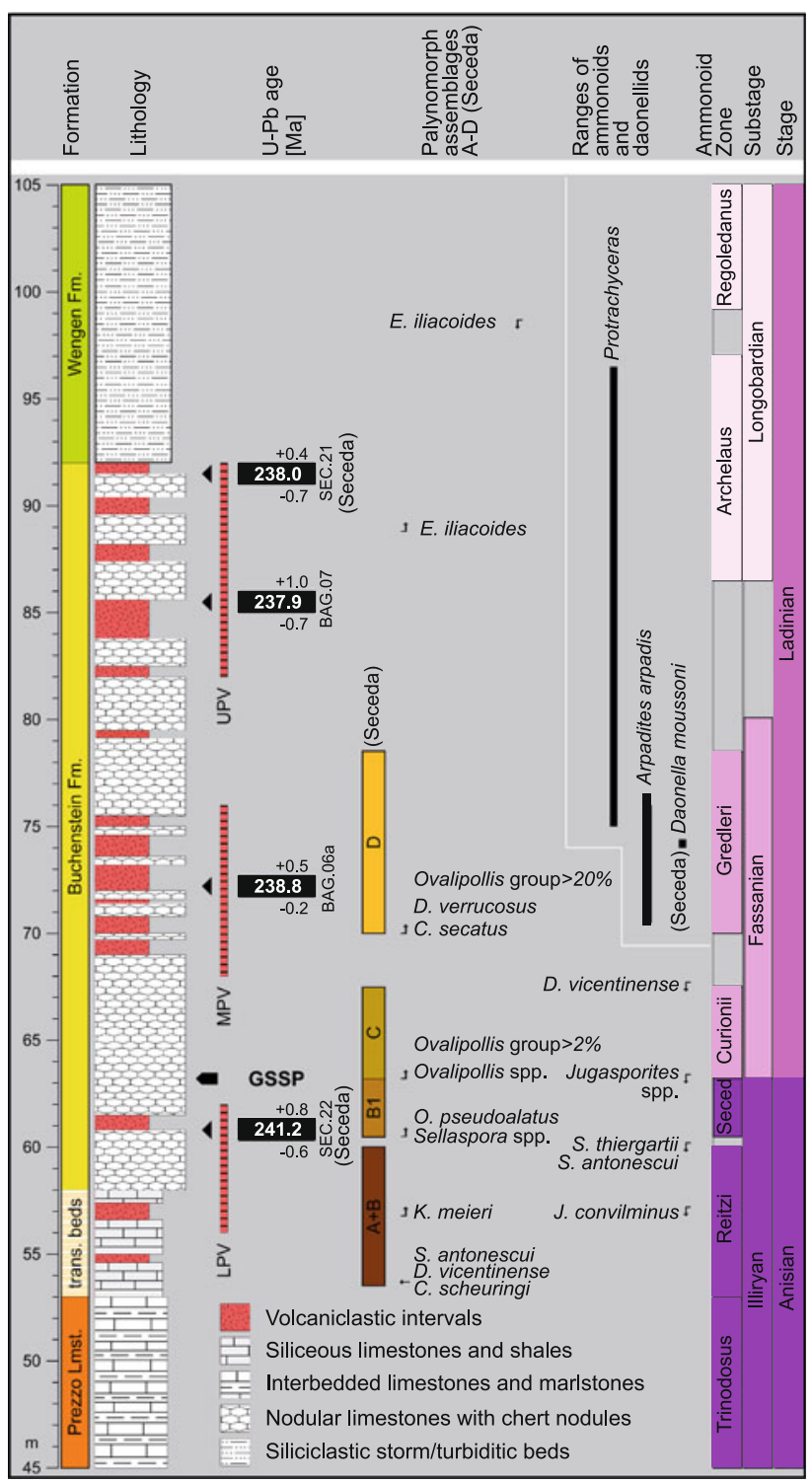

Fig. 3 Simplified stratigraphic log of Bagolino section (GSSP for the base of the Ladinian Stage) with U-Pb-zircon ages (BAG samples; Mundil et al. 1996) and distribution of ammonoid taxa co-occurring in the Ladinian section of Monte San Giorgio (Brack and Rieber 1993; Brack et al. 2005; Schatz 2005). Also shown are the correlatable $\mathrm{U}-\mathrm{Pb}$ zircon ages (SEC samples; Mundil et al. 1996) and biostratigraphic data on palynomorphs (Hochuli and Roghi 2002; Brühwiler et al. 2007) and daonellids (Schatz 2005) from Seceda, the principal auxiliary section in the Dolomites. The GSSP is defined by the lowest occurrence of the ammonoid Eoprotrachyceras curionii (base of the E. curionii Amm. Zone); it lies at the 63.25-m level of the Bagolino reference column. Ammonoid zonal scheme according to Brack and Rieber (1993), with the Fassanian Substage comprising both the E. curionii and P. gredleri Amm. Zones (Brack et al. 2005). LPV, MPV, $U P V$ Lower, Middle and Upper Pietra Verde intervals respectively

volcanic ash layers is very similar throughout the section. They consist of a grey microcrystalline matrix of mixedlayer illite-smectite clay minerals containing phenocrysts of alkali feldspar, quartz and sometimes euhedral biotite. 
Grain sizes of phenocrysts are usually less than 1-1.5 mm. Crystals of zircon and apatite are accessory components (Wirz 1945; Müller et al. 1964; Hellmann and Lippolt 1981). The euhedral zircon grains are usually long prismatic, colourless and very small, their size ranging between 0.2-0.3 mm (see also Wirz 1945; Mundil et al. 1996). Differently from the time-equivalent Pietra Verde volcaniclastic intervals, plagioclase is always lacking. Its absence is regarded as a primary feature by Müller et al. (1964), who consider the acid tuff layers of Monte San Giorgio as restricted to the Lake of Lugano region. Hellmann and Lippolt (1981), however, do not rule out the former presence of plagioclase in view of a possible later alteration to smectite (montmorillonite). The absence of detrital constituents, together with the widespread occurrence of very thin layers, suggests an air-borne origin with predominant sedimentation through subaqueous suspension-fall of ash following important subaerial eruptions. Zorn (1971) challenged the assumption of an essentially primary origin by stressing that in the coeval adjacent Salvatore platform similar layers were missing. However, tephra beds occur within the Salvatore Dolomite at Capo San Martino (Switzerland) and Brusimpiano (Italy; Bernoulli et al. 1976). At least a local lack of volcaniclastic intercalations is also known from the Buchenstein Formation area (Pietra Verde layers), where along the flanks of carbonate platforms these layers are found only sporadically. It is well possible that the volcaniclastic fallout in the platform settings has been washed out, adding to the background sedimentation in the adjacent basins (Brack and Rieber 1993).

\section{Biostratigraphy}

\subsection{Biostratigraphic data from previous studies}

The Besano Formation hosts a continuous macrofossil record (ammonoids and daonellid bivalves) ranging from the late Anisian (upper R. reitzi Amm. Zone) to the earliest Ladinian (lower E. curionii Amm. Zone) and represents a well-studied key section for the Anisian/Ladinian boundary. Ammonoids and daonellid bivalves allow a detailed correlation with other South-Alpine sections from eastern Lombardy to the Dolomites, supported by the occurrence of volcaniclastic layers which likely correlate to the Lower Pietra Verde interval (Brack and Rieber 1993 and references therein). The base of the Ladinian Stage (=base of the E. curionii Amm. Zone) lies in the uppermost part of the formation, around $2.4 \mathrm{~m}$ below the top (Brack et al. 2005). Above the Besano Formation, available biostratigraphic data are restricted to a small number of discrete horizons bearing index fossils (Fig. 4). Age-diagnostic macrofossils in the San Giorgio Dolomite are limited to the
Fig. 4 Measured composite stratigraphic log of the Ladinian succession at Monte San Giorgio with selected biostratigraphic data, U-Pb zircon dates and proposed biostratigraphic subdivisions. The $0-\mathrm{m}$ level in the stratigraphic column corresponds to Bed 85 of the Besano Formation ( $N$. secedensis Amm. Zone) in the standard profile at locality Mirigioli (Site P. 902; Rieber 1973b). It lies 4.5 below the base of the E. curionii Amm. Zone (base of the Ladinian Stage) and $1.45 \mathrm{~m}$ above the volcaniclastic Bed 71 (Rieber 1973b) dated by Mundil et al. (1996, 2010). Ammonoid and daonellid occurrences after Wirz (1945), Schatz (2005) and new data from Val Porina (Daonella moussoni) and Cassina (Protrachyceras cf. P. neumayri); above the Lower Meride Limestone neither ammonoid nor agediagnostic daonellid occurrences have been so far reported. Macrofossil occurrences within the Besano Formation are not indicated (see Brack and Rieber 1993; Brack et al. 2005). Palynomorph and radiolarian occurrences according to the present study. The radiolarian assemblages from the earliest Ladinian are correlatable with the E. curionii Amm. Zone and currently under study (see text for further discussion). Be Besano Formation, SGD San Giorgio Dolomite, LMe Lower Meride Limestone, DB Dolomitband, LKSZ, MKSZ, UKSZ Lower, Middle and Upper Kalkschieferzone

occurrence of Daonella longobardica reported by Senn (1924, p. 563), which is only questionably assignable to the E. curionii Amm. Zone (Schatz 2005, p. 100). Higher up in the sequence, the following index fossils have been so far reported by previous authors from limestone beds below the "Val Serrata tuff":

- Daonella moussoni (Merian, 1853) (Frauenfelder 1916, p. 279; Senn 1924, p. 563; Wirz 1945, p. 49; Schatz 2005, p. 100). Rieber (1969) attributed the material from the Frauenfelder and Wirz collections to Daonella aff. D. moussoni (Merian, 1853) while Schatz (2001, 2005) considered Daonella aff. D. moussoni and Daonella moussoni as conspecific.

- "Protrachyceras archelaus" (Laube, 1869) (Frauenfelder 1916, p. 279; Wirz 1945, p. 53) and "Protrachyceras cf. P. archelaus" (Senn 1924, p. 563). Some of the questionable specimens from these historical collections was re-determined by H. Rieber as Protrachyceras cf. P. ladinum (Mojsisovics, 1882) (Schatz 2001).

- Arpadites arpadis Mojsisovics, 1882 (Wirz 1945, p. 54).

Higher up, around $10 \mathrm{~m}$ above the "Val Serrata tuff", a specimen of Arpadites arpadis was collected during the 1998 palaeontological excavations by the University of Zurich at Acqua del Ghiffo in the Cava superiore beds (Schatz 2005). Further ammonoid specimens from the same fossiliferous interval have been determined as Arpadites cf. arpadis (Furrer 1999b, 2001).

In the following part of the section no age-diagnostic macrofossils have been so far reported. Detailed palynological data about the entire Kalkschieferzone were collected by Scheuring (1978) who also analysed two additional samples, one coming from the underlying Upper 


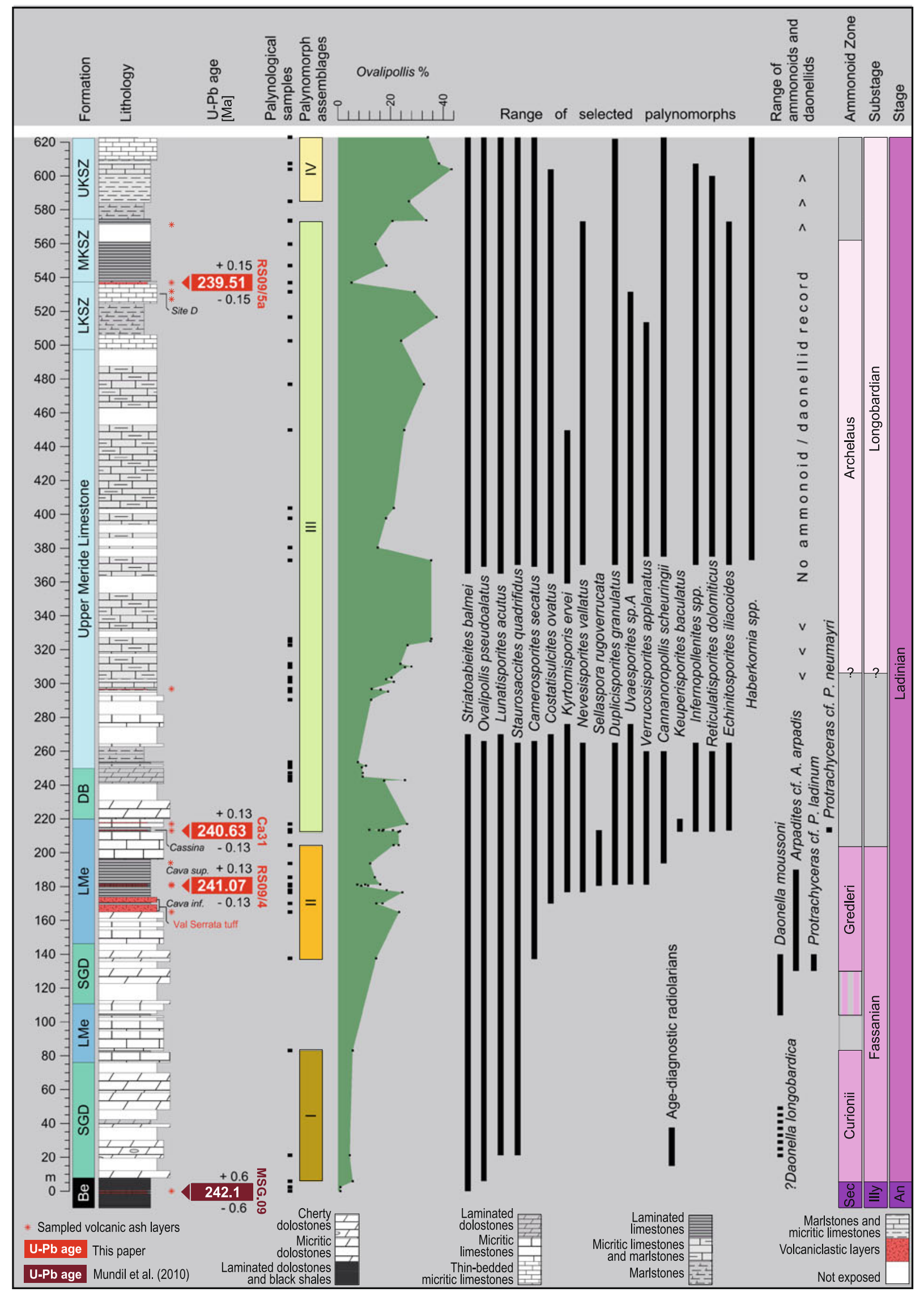



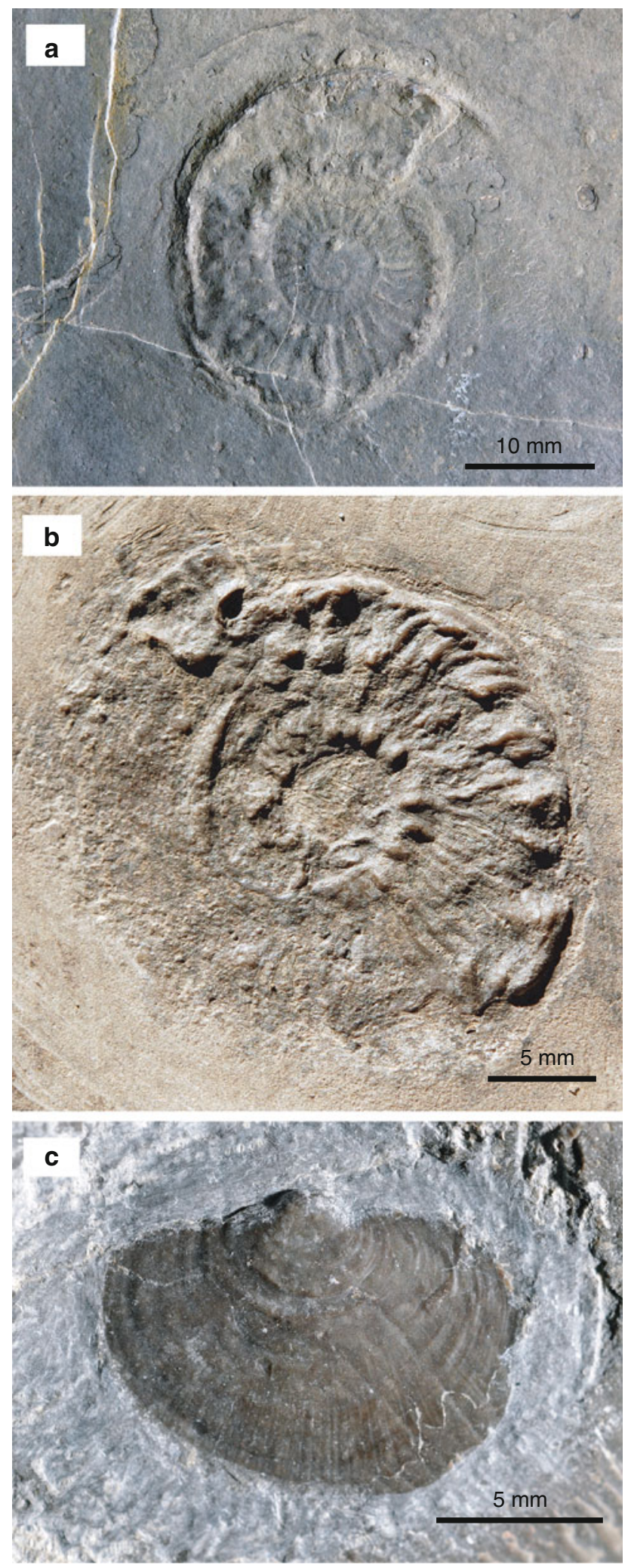

Meride Limestone (sample 95), the other from the Cassina beds of the Lower Meride Limestone (sample 90). He assigned all the studied samples to the Longobardian.
4 Fig. 5 Macrofossils from the Lower Meride Limestone. a Arpadites cf. A. arpadis Mojsisovics, 1882, MCSN 8376, P. gredleri Amm. Zone, Fassanian (early Ladinian). Lower Meride Limestone, Cava superiore beds, Val Serrata. b Protrachyceras cf. P. neumayri (Mojsisovics, 1882), MCSN 8377, transition interval between $P$. gredleri and P. archelaus Amm. Zones. Lower Meride Limestone, Cassina beds, Cassina. c Daonella moussoni (Merian, 1853), sinistral valve, MCSN 8375, P. gredleri Amm. Zone, Fassanian (early Ladinian). Lower Meride Limestone, Val Porina

\subsection{New biostratigraphic investigations}

\subsubsection{Material and methods}

In order to provide reliable biochronologic constraints to the new radio-isotopic dating, a more detailed biostratigraphic subdivision of the studied section has been attempted. This, in turn, will allow to outline the correlation with sections of the widespread pelagic Buchenstein Formation, from where both a detailed faunal record and radio-isotopic ages are available. Systematic sampling has been carried out throughout the entire section, focused on invertebrate macrofossils (ammonoids and daonellids) and age-diagnostic microfossils (conodonts and radiolarians). Bed-by-bed excavations have been performed in vertebrate-bearing horizons. To achieve a more continuous biostratigraphical record, a palynological study of the whole section was carried out. Seventy-six samples were taken from different lithologies: laminated dolostones and limestones, micritic dolostones and limestones, marlstones, cherts and volcanic ash-layers (bentonite). The lowermost sample (VP85 $=0-\mathrm{m}$ level in the stratigraphic column) comes from a bentonite layer of the middle Besano Formation (Val Porina mine) lying $1.45 \mathrm{~m}$ above Bed 71 in Mundil et al. (1996, 2010); see further below). The uppermost sample comes from the top of the Kalkschieferzone (Val Mara; Fig. 1a) defined according to Furrer (1995). Samples were crushed and weighed (20-30 g) and treated with hydrochloric and hydrofluoric acid according to the standard palynological method (Traverse 2007). The residues were sieved and strew mounted on standard microscope slides using Norland Optical Adhesive 61. Oxidation using Schulze's solution was usually applied due to the common occurrence of amorphous organic matter. Additional single spore and pollen grains have been picked from the dry residues of several samples processed for radiolarian and conodont micropalaeontological investigations. After crushing, these samples were treated with a $10 \%$ solution of formic acid, buffered with both calcium carbonate (20 g every litre of acid solution) and tri-calcium phosphate (1.2 g every litre of acid solution). After $24 \mathrm{~h}$, the muddy residue was separated, thoroughly wet sieved and dried. The process was repeated on each fragmented sample for 4-6 weeks. 


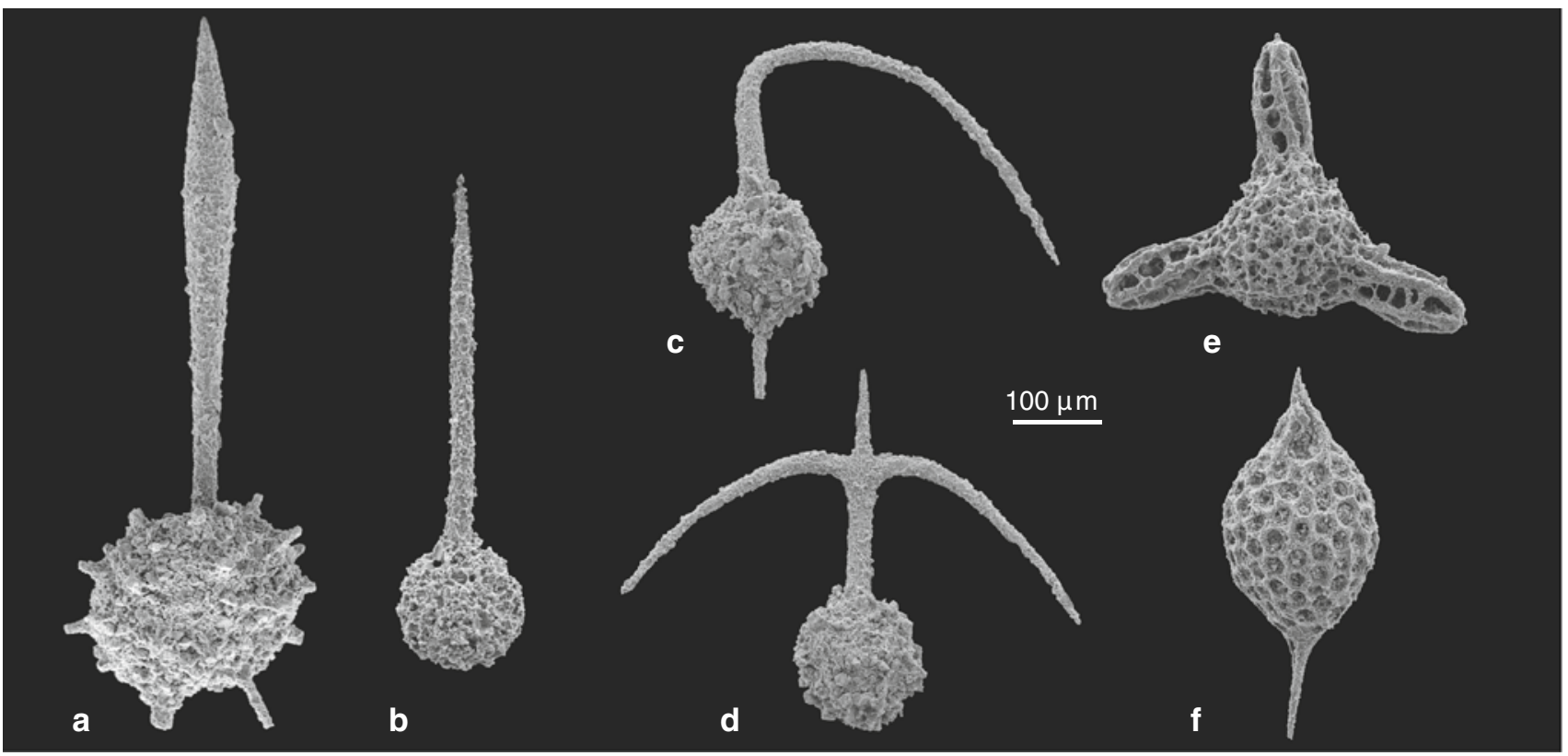

Fig. 6 Selected radiolarians from the San Giorgio Dolomite, E. curionii Amm. Zone, Fassanian (early Ladinian), Val Porina. Scanning electron (SEM) micrographs. a Paroertlispongus multispinosus Kozur and Mostler, 1981, sample Pm/23a. b Paroertlispongus rarispinosus Kozur and Mostler, 1981, sample M/6. c Oertlispongus

Radiolarians and selected sporomorphs were mounted on stubs and photographed with a Mira Tescan scanning electron microscope (SEM) at the Institut de Géologie et Paléontologie of the University of Lausanne (UNIL). All the studied material is deposited in the collection of the Museo cantonale di storia naturale, Lugano, Switzerland (MCSN). The ammonoid zonal scheme used in this paper is after Brack and Rieber (1993) and Brack et al. (2005).

Fig. 7 Selected Ladinian palynomorphs from the Monte San Giorgio section. Transmitted light micrographs unless otherwise specified. a Ovalipollis pseudoalatus (Thiergart, 1949) Schuurman, 1976, sample VM5, Middle Kalkschieferzone. b Ovalipollis sp., sample VM47, Middle Kalkschieferzone. c Staurosaccites quadrifidus Dolby in Dolby and Balme, 1976, sample VM5, Middle Kalkschieferzone. d Triadispora stabilis Scheuring, 1978, sample VM4, Middle Kalkschieferzone. e Striatoabieites balmei (Klaus, 1964) emend. Scheuring 1978, sample RS08-2a, Lower Meride Limestone. f Striatoabieites balmei (Klaus, 1964) emend. Scheuring 1978, sample RS09-5, Lower Kalkschieferzone. g Lunatisporites acutus (Leschik, 1955) emend. Scheuring, 1970, sample RS09-5, Middle Kalkschieferzone. h Lunatisporites noviaulensis mollis Scheuring, 1970, sample VM11, Upper Kalkschieferzone. i Infernopollenites sp., sample VM17, Upper Kalkschieferzone. j Cannanoropollis scheuringii Brugman (1986), sample VM34, Lower Kalkschieferzone. k Cannanoropollis scheuringii Brugman (1986), sample Ca 55, Lower Meride Limestone. SEM micrograph. I Keuperisporites baculatus Schulz, 1965, sample Ca55, Lower Meride Limestone. Incident blue light fluorescence micrograph. m Costatisulcites ovatus Scheuring, 1978, sample RS08/2a, Lower Meride Limestone. n Reticulatisporites dolomiticus Blendinger, 1988, sample VM-D10, Lower Kalkschieferzone. o Kyrtomisporis ervei Van der Eem 1983, sample Ca 13/14, Lower Meride Limestone. p Concavisporites sp. VM17, Upper inaequispinosus Dumitrica, Kozur and Mostler, 1980, sample Pm/2f d Baumgartneria retrospina Dumitrica, 1982, sample Pm/1e. e Eptingium manfredi Dumitrica, 1978, sample Sb/37d. f Pentactinocarpus fusiformis Dumitrica, 1978, sample M/b18a

\subsubsection{Results}

Fieldwork yielded some new ammonoid and bivalve finds (Figs. 4, 5). A small specimen of Arpadites cf. A. arpadis Mojsisovics, 1882 (det. H. Rieber 2011; Fig. 5a) was found in the laminated limestones of the Cava superiore beds outcropping in Val Serrata (Fig. 1a). A second ammonoid specimen came to light in September 2011 during a

Kalkschieferzone. q Sellaspora rugoverrucata Van der Eem 1983, sample VC7, Lower Meride Limestone. r Sellaspora rugoverrucata Van der Eem 1983, sample VC18, Lower Meride Limestone. s Nevesisporites vallatus De Jersey and Paten, 1964, sample VC6, Lower Meride Limestone. t Echinitosporites iliacoides Schulz and Krutzsch, 1961, sample VM-D10, Lower Kalkschieferzone. u Echinitosporites iliacoides Schulz and Krutzsch, 1961, sample Ca6, Lower Meride Limestone. v Echinitosporites iliacoides Schulz and Krutzsch, 1961, sample VM5, Middle Kalkschieferzone. w Duplicisporites granulatus (Leschik, 1955) Van der Eem 1983, sample VM-D10, Lower Kalkschieferzone. x Duplicisporites granulatus (Leschik, 1955) Van der Eem 1983, sample VM39, Middle Kalkschieferzone. y Camerosporites secatus Leschik, 1955 emen. Scheuring 1978, sample RS09-1, Lower Meride Limestone. $\mathbf{z}$ Camerosporites secatus Leschik, 1955 emen. Scheuring 1978, sample RS10-12, San Giorgio Dolomite. aa Camerosporites secatus Leschik, 1955 emen. Scheuring 1978, sample RS08-2a, Lower Meride Limestone. ab Uvaesporites argentaeformis (Bolkhovitina, 1953) Schulz, 1967, sample RS08-2a, Lower Meride Limestone. ac Uvaesporites gadensis PraehauserEnzenberg, 1970, sample RS08-2a, Lower Meride Limestone. ad Uvaesporites gadensis Praehauser-Enzenberg, 1970, sample RS10-12, San Giorgio Dolomite. ae Uvaesporites sp. A Van der Eem, 1983, sample VM13, Lower Meride Limestone 


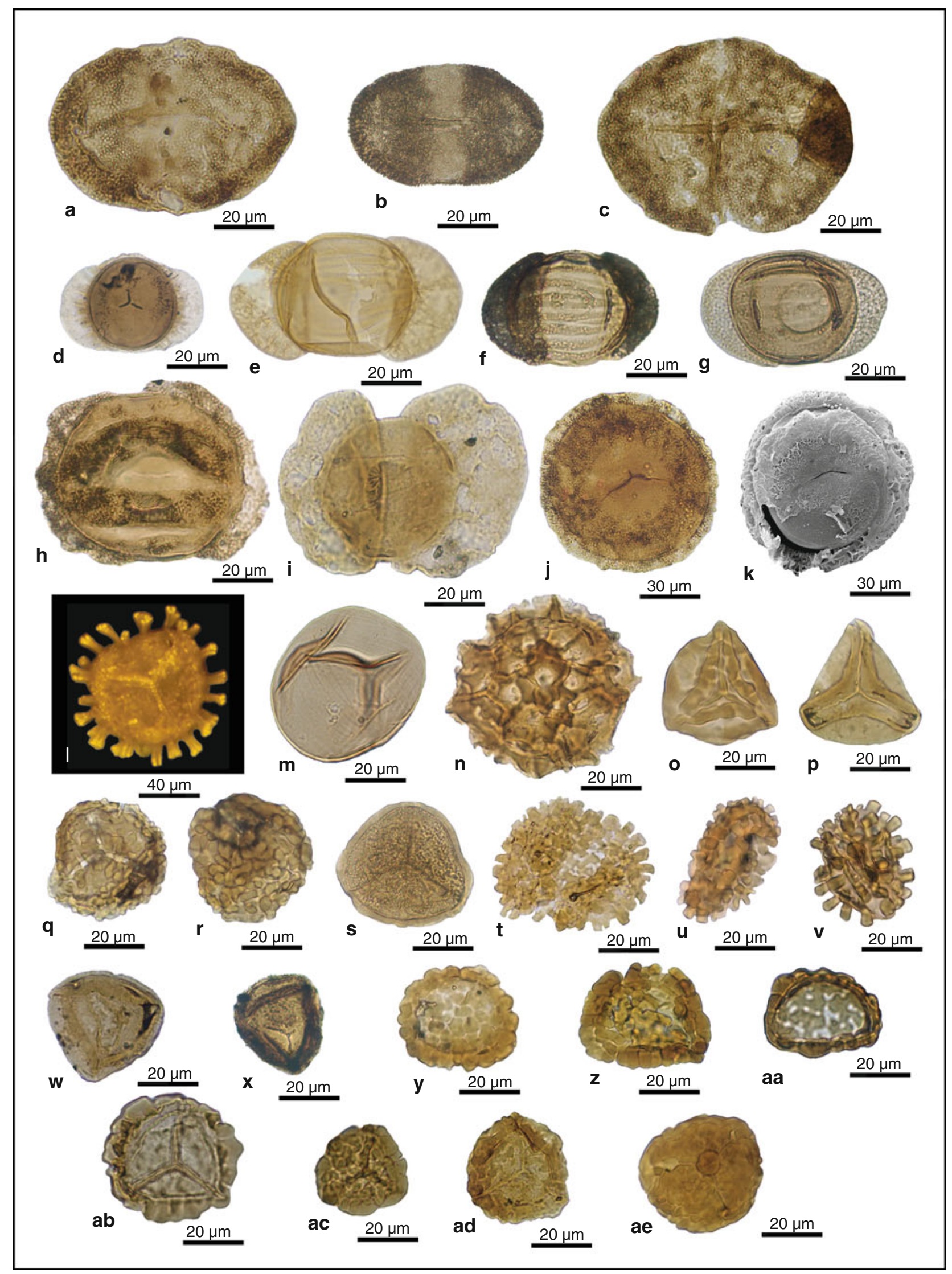


bed-by-bed excavation in the Cassina beds at Cassina (Fig. 5b); this specimen, assigned to Protrachyceras cf. $P$. neumayri (Mojsisovics, 1882) (det. H. Rieber 2011), represents the youngest ammonoid occurrence so far reported from the Meride Limestone. Moreover, in the Lower Meride Limestone of the Val Porina section a layer bearing rare Daonella moussoni (Merian, 1853) was discovered (Fig. 5c), which lowers the first occurrence of this taxon by around $20 \mathrm{~m}$ compared to Wirz (1945) and Schatz (2005). New vertebrate faunas from both the San Giorgio Dolomite and the Meride Limestone have also been brought to light, providing a more continuous record than so far assumed (see Fig. 2). They include actinopterygian fishes and sauropterygian reptiles. Recovered conodonts only consist of poorly diagnostic elements whose patchy occurrences are restricted to the San Giorgio Dolomite. Radiolarian investigations yielded moderately to well-preserved specimens, unfortunately limited to the lower part of the San Giorgio Dolomite. Some typical forms are illustrated here (Fig. 6), while a detailed description of the recovered assemblages will be presented in a forthcoming paper. Representatives of the family Oertlispongidae, the most important radiolarian family for the biochronology of the Tethyan late Anisian-Ladinian, are common (Fig. 6a-d), together with species belonging to Eptingidae (Fig. 6e) and Pentactinocarpidae (Fig. 6f).

Apart from spores and pollen grains, the palynological samples contained minor amounts of acritarchs, algal cysts and foraminiferal linings. Five samples did not yield palynomorphs suitable for determination. A feature common to most samples is the overwhelming occurrence of bisaccate pollen grains whereas the spores constitute less than $10 \%$ (most frequently around $5 \%$ ) of the association. Triadispora group and Ovalipollis group prevail over all other taxonomic groups with the exception of some ash-layers, where the spore number distinctly increases (to around $30 \%$ or even more). Both these features are in agreement with Scheuring (1978). Assemblages have been defined by the first (FO) and last occurrence (LO) of marker taxa and by the distribution of the main groups, Ovalipollis in particular, throughout the section (Hochuli and Roghi 2002). The relative distribution has been semiquantitatively assessed by counting between 100 and 200 determinated specimens per sample. Only the stratigraphically most relevant results are summarized here while a detailed palynological and palynofacies description is the object of a separate paper.

Four different palynological assemblages can be distinguished (Figs. 4, 7).

Assemblage I $(5.8-83 \mathrm{~m})$ is characterized by frequent Calamospora sp. and Triadispora spp. along with common Convolutispora sp., Striatoabieites balmei (Klaus, 1964) emend. Scheuring 1978, Lunatisporites acutus (Leschik,
$1955)$ emend. Scheuring, 1970, Uvaesporites gadensis Praehauser-Enzenberg, 1970 and Staurosaccites quadrifidus Dolby in Dolby and Balme, 1976. ?Gordonispora fossulata? (Balme, 1970) Van der Eem, 1983 appears at the top of the interval. Ovalipollis spp. constitute 5-6\% of the sporomorph assemblage. The two lowermost samples $(0.0$ and $2.4 \mathrm{~m}$ ) might also be included here. Even though Ovalipollis is seemingly missing, the palynological recovery of the latter samples is very poor and, in the case of sample VP-85, most likely lithology-dependent (bentonite sample, see above).

Assemblage II (137-204 m) is marked by the FO of Camerosporites secatus Leschik, 1955 emend. Scheuring 1978 and by the sudden increase of the Ovalipollis group ( $>15 \%$ of the palynomorphs), mainly represented by Ovalipollis pseudoalatus (Thiergart, 1949) Schuurman, 1976. Both these features represent a distinct floral change. The Triadispora group is the dominant constituent of the association. The following palynomorphs have their FO in this interval and are an important constituent of the assemblage: Nevesisporites vallatus De Jersey and Paten, 1964, Sellaspora rugoverrucata Van der Eem 1983, Kyrtomisporis ervei Van der Eem 1983, Duplicisporites granulatus morphon sensu Van der Eem 1983, Verrucosisporites applanatus Mädler, 1964, Uvaesporites sp. A sensu Van der Eem 1983, Costatisulcites ovatus Scheuring 1978, Cannanoropollis scheuringii Brugman, 1986, Kuglerina meieri Scheuring 1978, Concavisporites spp., Platysaccus spp. and Lunatisporites spp. Parillinites sp., already present in the Assemblage I, becomes from now on a common constituent. According to these new data, the FO of Camerosporites secatus is lowered by $380 \mathrm{~m}$ compared to Scheuring (1978) who did not report the occurrence of Circumpolles below the Kalkschieferzone.

Assemblage III (212-573 m) is distinguished by the FO of Echinitosporites iliacoides Schulz and Krutzsch, 1961, Infernopollenites spp., Keuperisporites baculatus Schulz, 1965 and Reticulatisporites dolomiticus Blendinger, 1988. This floral change first occurs at the base of the Cassina beds from where already Scheuring (1978, sample 90) reported the occurrence of Echinitosporites iliacoides. The Triadispora group still remains the dominant constituent of the association. The Ovalipollis group further increases ( $>21 \%$ of the sporomorphs). Protohaploxypinus spp. and Protodiploxipinus spp. appear and become common constituents of the association. Haberkornia spp. appear only in the upper part of the interval $(373 \mathrm{~m})$ where Duplicisporites granulatus becomes frequent. Echinitosporites iliacoides ranges up to the top of the Middle Kalkschieferzone; consequently, the LO of this species is raised by 37 m compared to Scheuring (1978).

Assemblage $I V$ is defined in the uppermost part of the section (585-622 m; Upper Kalkschieferzone), where 
Echinitosporites iliacoides no longer occurs. The Ovalipollis group reaches here its maximal frequence whereas for the first time the Triadispora group slightly decreases. Staurosaccites quadrifidus, Striatoabieites balmei, Parillinites spp., Lunatisporites spp. and, above all, Duplicisporites granulatus are common constituents of this assemblage.

\subsection{Interpretation}

In the Southern Alps, ammonoids belonging to the genus Arpadites range from the $P$. gredleri Zone to the $P$. archelaus Zone (Brack and Rieber 1993). In the GSSP section at Bagolino (Buchenstein Fm.; Fig. 3) Arpadites arpadis occurs at 70.5-76.5 m (Brack and Rieber 1993; Schatz 2005), that is below and above the dated Middle Pietra Verde volcaniclastic layer $(72.2 \mathrm{~m}$, sample BAG.06a), within the early Ladinian $P$. gredleri Zone (Mundil et al. 1996; Brack et al. 2005). According to the revision of Schatz (2001), Daonella moussoni and Protrachyceras cf. $P$. ladinum indicate the $P$. gredleri Zone as well; however, the range of $D$. moussoni may extend downwards into the transition interval between the P. gredleri and the E. curionii Zones (Schatz 2005), or even into the uppermost part of the latter (McRoberts 2010). Protrachyceras neumayri indicates the $P$. archelaus Zone.

The new vertebrate finds are currently under study, but their use as a high-resolution correlation tool outside the Monte San Giorgio basin is hampered by the possibility of some degree of endemism (e.g. Rieppel 2000; Stockar and Renesto 2011) and, above all, by the patchy occurrences of vertebrate fossils in the Ladinian of the Southern Alps and in the Buchenstein Formation in particular. From the latter, besides isolated fish and reptile remains at Seceda (Dolomites), only one vertebrate-rich level is so far known which has been assigned to the upper E. curionii Amm. Zone (Northern Grigna Mountain, Lombardy; Lombardo et al. 2008). Moreover, most of these vertebrate faunas still await a detailed description.

The radiolarian assemblages from the lower part of the San Giorgio Dolomite are assignable to the upper L. multiperforata Radiolarian Zone or to the transition interval between the latter and the M. firma Radiolarian Zone (Stockar et al. in prep.). Both these intervals correlate with the E. curionii Amm. Zone (Kozur 2003).

In-depth palynological investigations on the Ladinian GSSP at Bagolino (Southern Alps, Northern Italy) yielded no results (Mietto et al. 2003). By contrast, preliminary results from analyses of the auxiliary section at Seceda (Hochuli and Roghi 2002; Brühwiler et al. 2007) indicate some significant floral changes resulting in distinct assemblages (Fig. 3). They also allow a direct correlation of the widely used palynological phases introduced by Van der Eem (1983) for the Anisian and Ladinian stages with the corresponding ammonoid zones of Brack and Rieber (1993) and Brack et al. (2005). The resulting correlation scheme is mainly followed here.

Assemblage I (Fig. 4) correlates with Assemblage C of Hochuli and Roghi (2002; Fig. 3) on the basis, on the one side, of the occurrence of taeniate bisaccates and Ovalipollis spp. showing a frequence $>2 \%$ and, on the other side, of the absence of both Camerosporites secatus and Duplicisporites verrucosus Leschik, 1955 emend. Scheuring 1978 (=Duplicisporites granulatus morphon sensu Van der Eem 1983). According to Hochuli and Roghi (2002) this assemblage compares with the plurianulatus-novimundanus phase of Van der Eem (1983) and correlates with the early Fassanian E. curionii Amm. Zone. This is fully consistent with the ammonoid zonation suggested for the upper Besano Formation (Brack and Rieber 1993; Brack et al. 2005) and with the results of the current study of the radiolarian assemblages from the lower part of the San Giorgio Dolomite (see above). The two lowermost samples with very poor palynological contents belong to the late Anisian N. secedensis Amm. Zone according to Brack and Rieber (1993) and Brack et al. (2005).

Assemblage II is assigned to the plurianulatus-secatus phase of Van der Eem (1983) and conforms to the Assemblage D of Hochuli and Roghi (2002) on the basis of the distinct increase of the Ovalipollis group (from $>2 \%$ to $>20 \%$ in the Seceda section) and of the FO of Camerosporites secatus and Duplicisporites granulatus. According to Hochuli and Roghi (2002), this assemblage correlates with the late Fassanian P. gredleri Amm. Zone. In the Monte San Giorgio section, this attribution is also supported by the rare ammonoid and daonellid occurrences (see above). Downwards, the range of this assemblage (and consequently of the $P$. gredleri Amm. Zone) is poorly constrained due to outcrop conditions and lithologies unsuitable for yielding reliable palynological data.

Assemblage III is assigned to the secatus-dimorphus phase of Van der Eem (1983), mainly based on the distribution of Echinitosporites iliacoides, an important marker restricted to this phase (Van der Eem 1983; Brühwiler et al. 2007). According to Brugman (1986), the secatus-dimorphus phase corresponds to the P. gredleri and P. archelaus Amm. Zones. More recently, relying on new data from the Seceda drill hole (Brack et al. 2000; Hochuli and Roghi 2002) where this palynomorph first occurs in the Upper Pietra Verde interval, Brühwiler et al. (2007) regarded the range of E. iliacoides as being restricted to the $P$. archelaus Amm. Zone. However, in the section of Caprile (Dolomites) E. iliacoides already occurs in the Middle Pietra Verde within the $P$. gredleri Amm. Zone (Van der Eem 1983; Brack et al. 1999). According to Roghi (1995, 1997), in the Southern Alps Keuperisporites baculatus first 
appears in the $P$. longobardicum Amm. Subzone sensu Mietto and Manfrin (1995) which correlates to the lower part of the P. archelaus Amm. Zone sensu Brack and Rieber (1993). Also the occurrence of Protrachyceras cf. $P$. neumayri would suggest the early Longobardian $P$. archelaus Amm. Zone. We suggest, therefore, to assign the range of the Assemblage III to the $P$. archelaus Amm. Zone but also to extend it downwards at least into the transition interval between the latter and the $P$. gredleri Amm. Zone.

The main characteristic of Assemblage IV is the absence of Echinitosporites iliacoides. Since the last occurrence of this marker in the Seceda drill hole is between the E. archelaus and the $F$. regoledanus Amm. Zones (Brühwiler et al. 2007; Fig. 3), this assemblage could belong to the same transitional interval. This is supported by the absence of Enzonalasporites vigens Leschik, 1956, which is an important index species of the late Longobardian F. regoledanus Amm. Zone (Cirilli 2010).

\section{Geochronology}

\subsection{Radio-isotopic ages from previous studies}

Among the earlier radio-isotopic age data of particular significance for the Triassic geochronology one must mention the $\mathrm{K}-\mathrm{Ar}$ and ${ }^{40} \mathrm{Ar} /{ }^{39} \mathrm{Ar}$ ages of Hellmann and Lippolt (1981), determined on K-feldspars from upper Anisian bentonite beds of the Besano Formation of Monte San Giorgio. At that time, these results represented the by far best documented tie between Triassic biostratigraphic and chronologic time scales. The obtained $\mathrm{K}-\mathrm{Ar}$ age of $232 \pm 9 \mathrm{Ma}$ (combining results from several horizons), supported by the analyses performed by ${ }^{40} \mathrm{Ar} /{ }^{39} \mathrm{Ar}$ techniques which yielded a plateau age of $233 \pm 7 \mathrm{Ma}$, induced Forster and Warrington (1985) to propose an age of $235 \pm 5 \mathrm{Ma}$ for the Anisian/Ladinian boundary. Hellmann and Lippolt's results deeply influenced the timescale compilations until the mid-1990s (Gradstein et al. 1994) and even later (Gradstein et al. 2004), despite the radioisotopic ages produced in the mean time by Mundil et al. (1996), which seriously questioned Hellmann and Lippolt's datings. The bentonite Bed 71 of the middle Besano Formation (numbering according to the reference profile at Mirigioli; Rieber 1973b), dated to $226 \pm 7$ Ma by Hellmann and Lippolt (1981) using conventional K-Ar technique on a feldspar mixture, was later re-sampled by Mundil et al. (1996; sample MSG.09, air abrasion pretreatment technique) yielding a significantly older $\mathrm{U}-\mathrm{Pb}$ zircon age of $241.2 \pm 0.8 \mathrm{Ma}$. A further refinement was achieved by Mundil et al. (2010) who obtained for the sample MSG.09 a U-Pb zircon age of $242.1 \pm 0.6 \mathrm{Ma}$ using annealing followed by chemical abrasion (CA-TIMS), a pre-treatment technique effectively resulting in zircon crystals having a closed isotopic system (Mattinson 2005). Since the Bed 71 belongs to the N. secedensis Amm. Zone (Brack and Rieber 1993) and lies around $6 \mathrm{~m}$ below the base of the E. curionii Amm. Zone, an age of 242 Ma has been proposed for the Anisian/Ladinian boundary (Mundil et al. 2010).

Reliable radio-isotopic ages for the overlying Ladinian sequence of Monte San Giorgio were not available until now. Hellmann and Lippolt (1981; same methods as above) reported a $225 \pm 2$ Ma date for the high-sanidine phenocrysts of the Val Serrata tuff (Lower Meride Limestone), an age which is clearly too young (see also above for a comparison with results using new high-resolution methods). It is worth mentioning that the same authors also collected a bentonite sample from the palaeontological excavation site of the University of Zurich at Cassina (sample C1); however, this sample, likely from the same bed as our Ca31, did not yield any feldspar suitable for radiometric dating and, consequently, no age data were produced at that time (Hellmann and Lippolt 1981, p. 77).

\subsection{New radio-isotopic dating}

\subsubsection{Material and methods}

Twenty-two U-Pb determinations have been made on zircons from three ash layers selected for radio-isotopic dating (Figs. 1a, 2, 4). The mineralogical composition of these layers is dominated by a clay fraction composed of smectite or regular mixed-layer of illite-smectite type with some illite. K-feldspar (2.24-5.37 \%) always prevails over quartz $(1.23-2.45 \%$ ), thus substantiating a primary (airborne) volcanic origin of these beds. The dated layers are listed here in ascending stratigraphic order.

Sample RS09/4. Swiss National Coordinates: 717'190/ 85'410 (small creek $500 \mathrm{~m} \mathrm{NNE}$ of Cassina). Lower Meride Limestone, lower part of Cava superiore beds, around $7 \mathrm{~m}$ above the "Val Serrata tuff". Bentonite layer, grey in colour, $3 \mathrm{~cm}$ thick, interbedded between laminated limestones. A further bentonite layer, $2 \mathrm{~cm}$ thick, lies around $70 \mathrm{~cm}$ above the sampled bed. The sampled bed is a reliable marker horizon, belonging to a stratigraphic interval that can be identified in many other localities of Monte San Giorgio, e.g. at Valle della Cassina and Acqua del Ghiffo near Crocifisso. In the latter locality, this bentonite layer cross-cuts an old small gallery opened in the beds excavated in 1928 and 1997-2005 by the Palaeontological Institute and Museum of the University of Zurich (PIMUZ). Recovered vertebrate fossils include marine reptiles (Ceresiosaurus calcagnii, Neusticosaurus edwardsii, N. peyeri) and fishes (Saurichthys sp., Eosemionotus 
sp., Besania micrognathus) (Peyer 1931; Sander 1989; Furrer 1999a, 2001, 2003; Stockar and Renesto 2011).

Sample Ca31. Swiss National Coordinates: 716'990/ $85^{\prime} 150$ (palaeontological excavation site at Cassina). Lower Meride Limestone, Cassina beds. Bentonite layer, weathered to an orange colour, $5 \mathrm{~cm}$ thick, intercalated between the laminated limestones of this fossiliferous interval yielding marine reptiles (Ceresiosaurus lanzi, Neusticosaurus edwardsii, N. peyeri, Macrocnemus bassanii, Tanystropheus meridensis) and fishes (Saurichthys macrocephalus, S. curionii, "Archaeoseomionotus" sp., Eoeugnathus sp., Eosemionotus sp., Peltopleurus sp.) as well as land plant remains and quasi-anaerobic foraminiferal faunas (Peyer 1931; Rieppel 1985; Bürgin 1999; Hänni 2004; Stockar 2010; Stockar and Kustatscher 2010; Stockar and Renesto 2011). It is the main bentonite layer of the Cassina beds, currently excavated by the Museo cantonale di storia naturale (Lugano).

Sample RS09/5a. Swiss National Coordinates: 716'960/ $83^{\prime} 425$ (Val Mara). Top of the Lower Kalkschieferzone (sensu Furrer 1995). Bentonite bed, grey in colour, around $1.8 \mathrm{~m}$ thick, rich in very fresh euhedral biotite phenocrysts. It is interbedded between a 2-m-thick stack of thin-bedded limestones (below) and a $40 \mathrm{~cm}$ thick massive limestone bed (above); a further ash layer, $11 \mathrm{~cm}$ thick and compositionally equivalent, lies $2.3 \mathrm{~m}$ below this bed. The sampled bed is the thickest bentonite horizon in the Monte San Giorgio section and the most reliable marker horizon of the Kalkschieferzone. Furrer (1995) relates it to a single very important volcanic ash fall event. The sampled ash layer corresponds to the 103/106 bed in Scheuring (1978), bearing the exceptionally well-preserved palynoflora illustrated in his monograph. Moreover, it lies about $25 \mathrm{~m}$ below the vertebrate beds in the Middle Kalkschieferzone (Bürgin 1995; Furrer 1995) and $6 \mathrm{~m}$ above a fossiliferous horizon investigated in 1997-2003 by the University of Milan and the Museo cantonale di storia naturale (Lugano) at the so-called "Site D" (Val Mara; Fig. 1a). Here, bedby-bed excavations yielded diversified fish faunas besides crustaceans, terrestrial plants and insects (Krzeminski and Lombardo 2001; Lombardo 2002; Lombardo and Tintori 2004; Tintori and Lombardo 2007).

Zircon grains were extracted by standard mineral separation techniques. All the zircons analysed have undergone the (CA, thermal annealing and subsequent leaching) pretreatment technique (Mattinson 2005) for the effective elimination of $\mathrm{Pb}$-loss. This involved placing the zircons in a muffle furnace at $900 \pm 20{ }^{\circ} \mathrm{C}$ for $\sim 60 \mathrm{~h}$ in quartz beakers before being transferred to $3 \mathrm{ml}$ Savillex beakers, placed in a Parr vessel, and leached in a $\sim 5: 1 \mathrm{mix}$ of $29 \mathrm{M}$ $\mathrm{HF}+30 \% \mathrm{HNO} 3$ for $12 \mathrm{~h}$ at $\sim 180{ }^{\circ} \mathrm{C}$. The acid solution was removed, and fractions were rinsed in ultrapure $\mathrm{H}_{2} \mathrm{O}$, fluxed on a hotplate at $\sim 80{ }^{\circ} \mathrm{C}$ for an hour in $6 \mathrm{M} \mathrm{HCl}$, ultrasonically cleaned for an hour, and then placed back on the hotplate for an additional $30 \mathrm{~min}$. The $\mathrm{HCl}$ solution was removed and the fractions (single zircon crystals or fragments) were selected, photographed and again rinsed (in ultrapure acetone) prior to being transferred to $300 \mu \mathrm{l}$ Teflon FEP microcapsules and spiked with a mixed ${ }^{233} \mathrm{U}^{235} \mathrm{U}{ }^{205} \mathrm{~Pb}$ tracer. Zircon was dissolved in $\sim 120 \mu \mathrm{l}$ of $29 \mathrm{M} \mathrm{HF}$ with a trace amount of $30 \% \mathrm{HNO}_{3}$ with microcapsules placed in Parr vessels at $\sim 220{ }^{\circ} \mathrm{C}$ for $48 \mathrm{~h}$, dried to fluorides, and then converted to chlorides at $\sim 180{ }^{\circ} \mathrm{C}$ overnight. $\mathrm{U}$ and $\mathrm{Pb}$ for all minerals were separated using standard $\mathrm{HCl}$-based anion-exchange chromatographic procedures. Isotope ratios were measured at the NERC Isotope Geosciences Laboratory (NIGL), British Geological Survey, UK, using a Thermo-Electron Triton Thermal Ionisation Mass-Spectrometer (TIMS). $\mathrm{Pb}$ and $\mathrm{U}$ were loaded together on a single Re filament in a silica-gel/phosphoric acid mixture. $\mathrm{Pb}$ was measured by peak-hopping on a single SEM detector. U isotopic measurements were made in static Faraday mode. Age calculations (including U/Th disequilibrium) and uncertainty estimation were based upon the algorithms of Schmitz and Schoene (2007). All ${ }^{206} \mathrm{~Pb} /{ }^{238} \mathrm{U}$ dates are calculated using the ${ }^{238} \mathrm{U}$ and ${ }^{235} \mathrm{U}$ decay constants of Jaffey et al. (1971) and corrected for initial U/Th disequilibrium using an assumed $\mathrm{Th} / \mathrm{U}$ magma ratio of 4 , typical for magmatic systems. The consensus value of ${ }^{238} \mathrm{U} /{ }^{235} \mathrm{U}=137.88$ (Steiger and Jäger 1977) was used in the data reduction calculations. For U-Pb dates of this age the ${ }^{206} \mathrm{~Pb} /{ }^{238} \mathrm{U}$ dates are the most precise and robust. In contrast, the ${ }^{207} \mathrm{~Pb}$-based dates $\left({ }^{207} \mathrm{~Pb} /{ }^{235} \mathrm{U}\right.$ and ${ }^{206} \mathrm{~Pb} /{ }^{207} \mathrm{~Pb}$ ) are considerably less precise and hence are only used to assess concordance of the U-Pb (zircon) systematics.

\subsubsection{Results}

Table 1 lists the ${ }^{206} \mathrm{~Pb} /{ }^{238} \mathrm{U}$ dates and uncertainties for each of the individual zircon analyses while the results are summarised in Figs. 8, 9. Removal through CA zircon pretreatment of domains with possible lead loss allows the youngest clusters in Figs. 8 and 9 to be used. The new radio-isotopic age determinations are consistent with the stratigraphic succession of the samples and with the $\mathrm{U}-\mathrm{Pb}$ date of Mundil et al. (2010) for the Besano Formation. Their precision allows even a relatively small stratigraphic thickness (32 m) as that between samples RS09/4 and Ca31 to be chronologically resolved.

Sample RSO9/4. Seven zircons were analysed with ${ }^{206} \mathrm{~Pb} /{ }^{238} \mathrm{U}$ dates ranging from 246.45 to $241.00 \mathrm{Ma}$. The three youngest grains ( $\mathrm{z} 5, \mathrm{z} 6$ and $\mathrm{z} 7)$ form a population of coherent and equivalent analyses with a weighted mean ${ }^{206} \mathrm{~Pb} /{ }^{238} \mathrm{U}$ date of $241.07 \pm 0.13 \mathrm{Ma}(\mathrm{MSWD}=3.0)$. The 


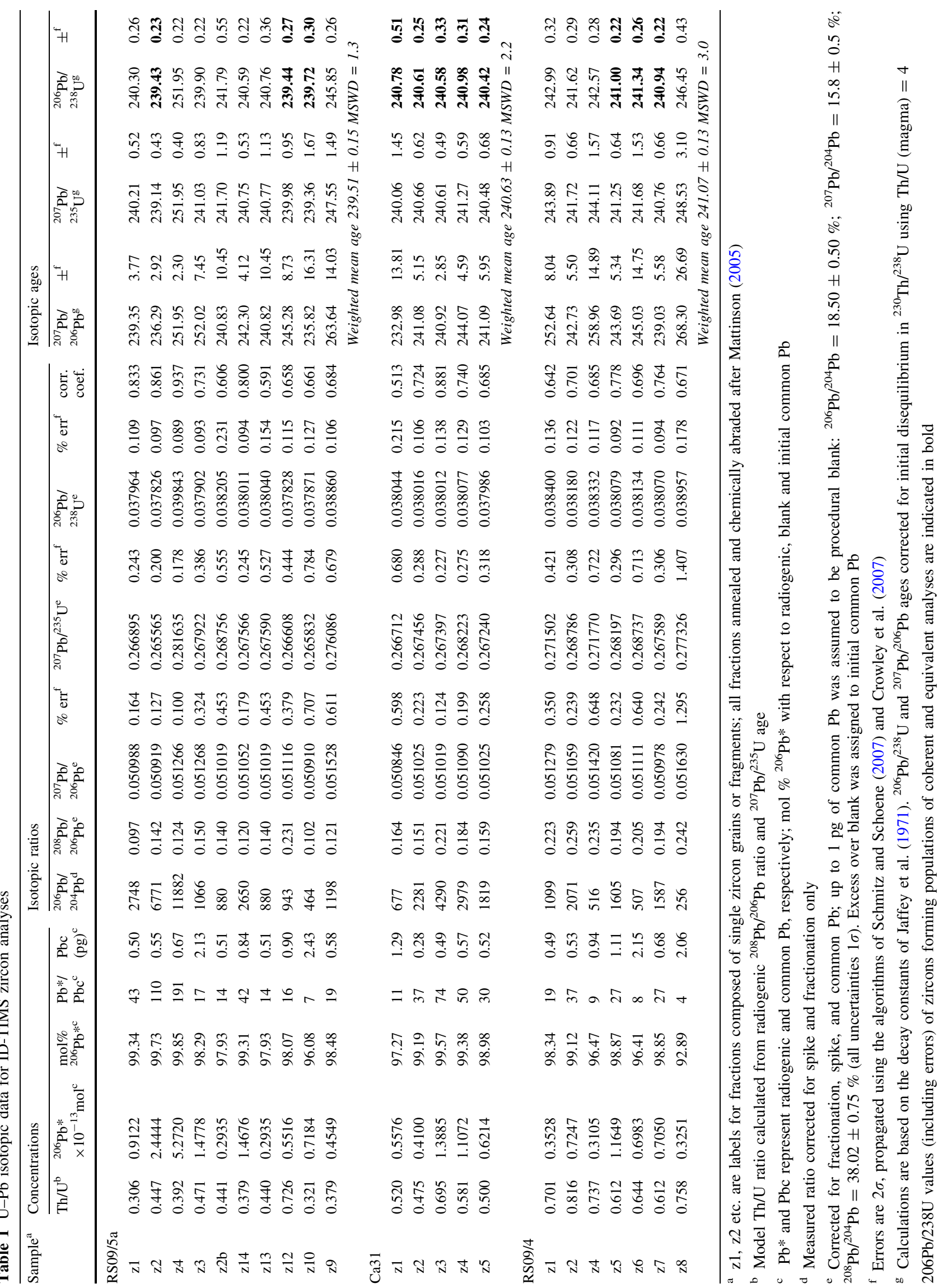




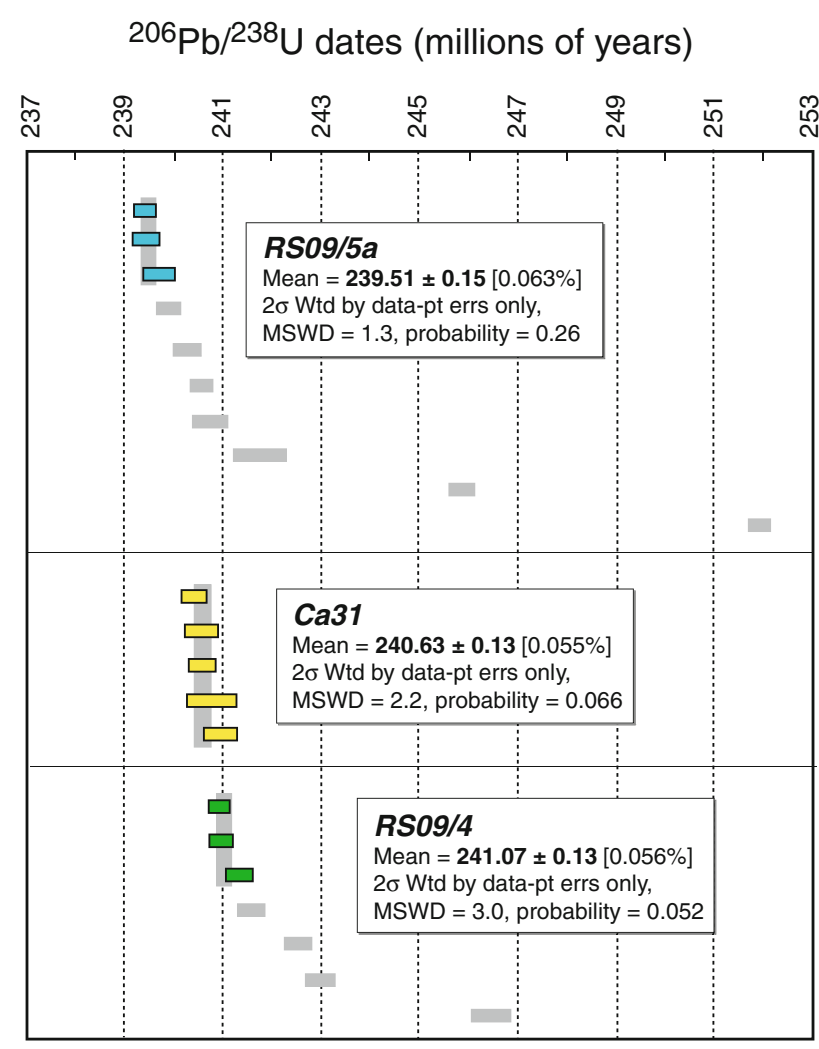

Fig. 8 Plot of all ${ }^{206} \mathrm{~Pb} /{ }^{238} \mathrm{U}$ zircon dates grouped by sample. Bars reflect a qualitative representation of the sample age uncertainty (see text for further discussion)

MSWD value is within the range of acceptable values for the given number of data points (Wendt and Carl 1991). Inclusion of z2, which is only just slightly older, would increase the weighted mean ${ }^{206} \mathrm{~Pb} /{ }^{238} \mathrm{U}$ date by ca. 0.03 Myr but the MSWD would exceed the acceptable range for the given number of data points. The remaining older zircon dates are excluded and interpreted as reflecting the reworking of older material in the magmatic environment.

Sample Ca31. Five zircons were analysed with ${ }^{206} \mathrm{~Pb} /{ }^{238} \mathrm{U}$ dates ranging from 240.98 to $240.42 \mathrm{Ma}$. All five analyses form a population of coherent and equivalent analyses with a weighted mean ${ }^{206} \mathrm{~Pb} /{ }^{238} \mathrm{U}$ date of $240.63 \pm 0.13 \mathrm{Ma}$ (MSWD = 2.2). The MSWD value is within the range of acceptable values for the given number of data points (Wendt and Carl 1991).

Sample RSO9/5a. Ten zircons were analysed with ${ }^{206} \mathrm{~Pb} /{ }^{238} \mathrm{U}$ dates ranging from 251.95 to $239.43 \mathrm{Ma}$. The three youngest grains (z2, z10 and z12) form a population of coherent and equivalent analyses with a weighted mean ${ }^{206} \mathrm{~Pb} /{ }^{238} \mathrm{U}$ date of $239.51 \pm 0.15 \mathrm{Ma}(\mathrm{MSWD}=1.3)$. The MSWD value is within the range of acceptable values for the given number of data points (Wendt and Carl 1991). Inclusion of z3, which is only just slightly older, would

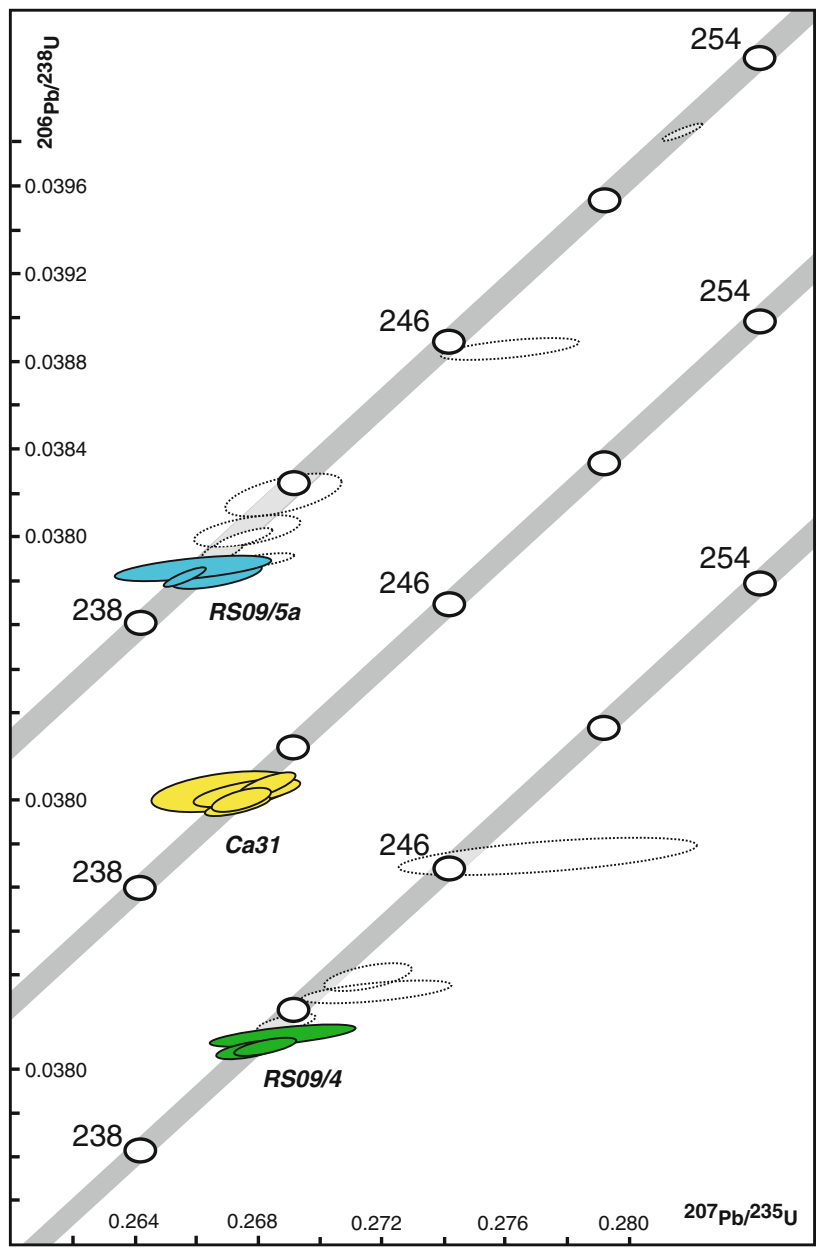

Fig. $9 \mathrm{U}-\mathrm{Pb}$ zircon dates plotted on conventional (Wetherill) concordia plots for the three samples analysed. Error ellipses that are dashed and semi-transparent reflect analyses excluded from the final age assignment (see text for further discussion). Data-point error ellipses are $2 \sigma$

increase the weighted ${ }^{206} \mathrm{~Pb} /{ }^{238} \mathrm{U}$ date by ca. $0.12 \mathrm{Myr}$ with the MSWD exceeding the acceptable range for the given number of data points. The remaining older zircon dates are excluded and interpreted as reflecting the reworking of older material in the magmatic environment.

The interpreted dates discussed above are the weighted average ${ }^{206} \mathrm{~Pb} /{ }^{238} \mathrm{U}$ dates calculated using Isoplot (Ludwig 1991) with the weighted mean uncertainties calculated as the ' $2 \sigma$ internal' error where the error is propagated from the assigned data-point errors alone. As discussed above, obvious outliers have been excluded and considered as derived from inherited older material. As levels of analytical precision have increased over the past decade (due to lower analytical blanks and improvements in mass spectrometry) it has become clear that sources of systematic uncertainty have to be considered when comparing data from different studies. In U-Pb ID-TIMS geochronology the two main sources of systematic error relate to: (1) the 
error in the calibration of the tracer employed in the study, and (2) the ${ }^{238} U$ decay constant. The magnitude of these two sources of error is estimated at 0.1 and $0.11 \%$ respectively (Jaffey et al. 1971; Condon et al. 2007). Accordingly, uncertainty would increase up to \pm 0.27 $0.28 \mathrm{Myr}$ (analytical + tracer error) and $\pm 0.45 \mathrm{Myr}$ (analytical + tracer $+{ }^{238} \mathrm{U}$ decay constant error).

\section{Discussion}

\subsection{Comparison with other sections and bio/ chronostratigraphic correlation}

The correlation between the lower third of the Monte San Giorgio section and the GSSP-section at Bagolino is possible on the basis of co-occurring ammonoids, daonellids and palynomorphs, also taking into account complementary data from Seceda (Fig. 10). The Upper Besano Formation, San Giorgio Dolomite and most of the Lower Meride Limestone are thus assignable to the Fassanian E. curionii and P. gredleri Amm. Zones and correlate to the lower and middle part of the Buchenstein Formation. The interval of the Lower Meride Limestone between, and including, the Val Serrata tuff and the Cava superiore beds bears a high concentration of volcanic ash layers (among which the radio-isotopically dated sample RS09/4), and likely correlate with the Middle Pietra Verde of the Bagolino section. Cassina beds may be assigned to the transition interval between the $P$. gredleri and the $P$. archelaus Amm. Zones. Therefore, the radio-isotopically dated ash layer occurring within the Cassina beds (sample Ca31) might be correlatable with the tuff layer at the 79-80-m level of the Bagolino section, which is comprised between the Middle and the Upper Pietra Verde intervals. For the overlying part of the Monte San Giorgio section up to the top of the Middle Kalkschieferzone, assigned to the $P$. archelaus Amm. Zone, a correlation with the upper part of the Buchenstein Formation and the lower part of the Wengen Formation at Bagolino may be inferred. Volcanic ash layers occur also in this interval of the Monte San Giorgio section, but they are usually thinner and much more widely spaced compared to the Lower Meride Limestone, making a correlation with the (Upper) Pietra Verde intervals less evident. Several bentonite beds, however, especially occur at the top of the Lower Kalkschieferzone, including the thick radio-isotopically dated volcanic ash layer (sample RS09/5a). This interval most likely corresponds to the Upper Pietra Verde. The Upper Kalkschieferzone, where volcanic ash layers have not been observed, correlates with the Wengen Formation, most likely to the interval belonging to the transition between the $P$. archelaus and $F$. regoledanus Amm. Zones.
The correlation proposed here indicates that the $\mathrm{U}-\mathrm{Pb}$ zircon age of Pietra Verde horizons within the $P$. gredleri and $P$. archelaus Zones at Bagolino and Seceda (Mundil et al. 1996) are up to $2 \mathrm{Myr}$ younger compared to our new age data. The pre-CA-treatment radio-isotopic ages from Bagolino and Seceda most likely result from remaining effects of $\mathrm{Pb}$ loss, which had not been successfully removed by the then standard air abrasion technique (see Mundil et al. 1996, 2010; Brack et al. 2007). However, the new radio-isotopic ages for samples RS09/4, Ca31 and RS09/5a as well as the suggested correlation of the sections at Monte San Giorgio and Bagolino are consistent with the age trend indicated for Bagolino on the basis of new data (Fig. 10; see also Brack et al. 2007: fig. 11).

The radio-isotopic date of $241.07 \pm 0.13$ Ma may thus be considered as a reliable age for the P. gredleri Amm. Zone, defined by both macrofossil and palynological data, and for the Middle Pietra Verde interval of the Buchenstein Formation. The age of $240.63 \pm 0.13 \mathrm{Ma}$ from the Cassina beds provides an upper age limit for the Middle Pietra Verde. The $239.51 \pm 0.15 \mathrm{Ma}$ age from the Lower Kalkschieferzone is within the age-range of the Upper Pietra Verde interval and dates a level in the $P$. archelaus Amm. Zone. This overlaps within error with the age of $239.3 \pm 0.2$ Ma obtained by Brühwiler et al. (2007) for a volcaniclastic layer at a similar stratigraphic position in the Austroalpine Reifling Formation (a pelagic unit comparable to the Buchenstein Formation) at Flexenpass (Austria; Fig. 1b).

The new bio- and chronostratigraphic assignment implies an older age of the Lower Kalkschieferzone than what was assumed in recent studies (latest Ladinian; e.g. Tintori and Lombardo 1999; Lombardo et al. 2011; Scheyer et al. 2011). It also implies an older age of the Cassina beds and subsequent strata at Monte San Giorgio compared with the tentative correlation of Furrer et al. (2008: fig. 5), who envisaged a correspondence of this interval with the Wengen Formation at Bagolino. However, the new age assignment is consistent with the scheme of Gianolla et al. (1998), suggesting a hiatus between the Kalkschieferzone and the overlying Pizzella Marls (Carnian). It also supports the correlation of the Kalkschieferzone with the upper part of the Cunardo Formation (western Varese Province, Italy; Fig. 1b), which, on the basis of ammonoid occurrences, has been ascribed to the P. archelaus Amm. Zone (Calabrese and Balini 1995).

\subsection{Sedimentation rates}

The proposed correlation implies striking differences in thicknesses of corresponding intervals (Fig. 11), reflecting much higher sedimentation rates in the depositional setting of the Monte San Giorgio section compared to the 


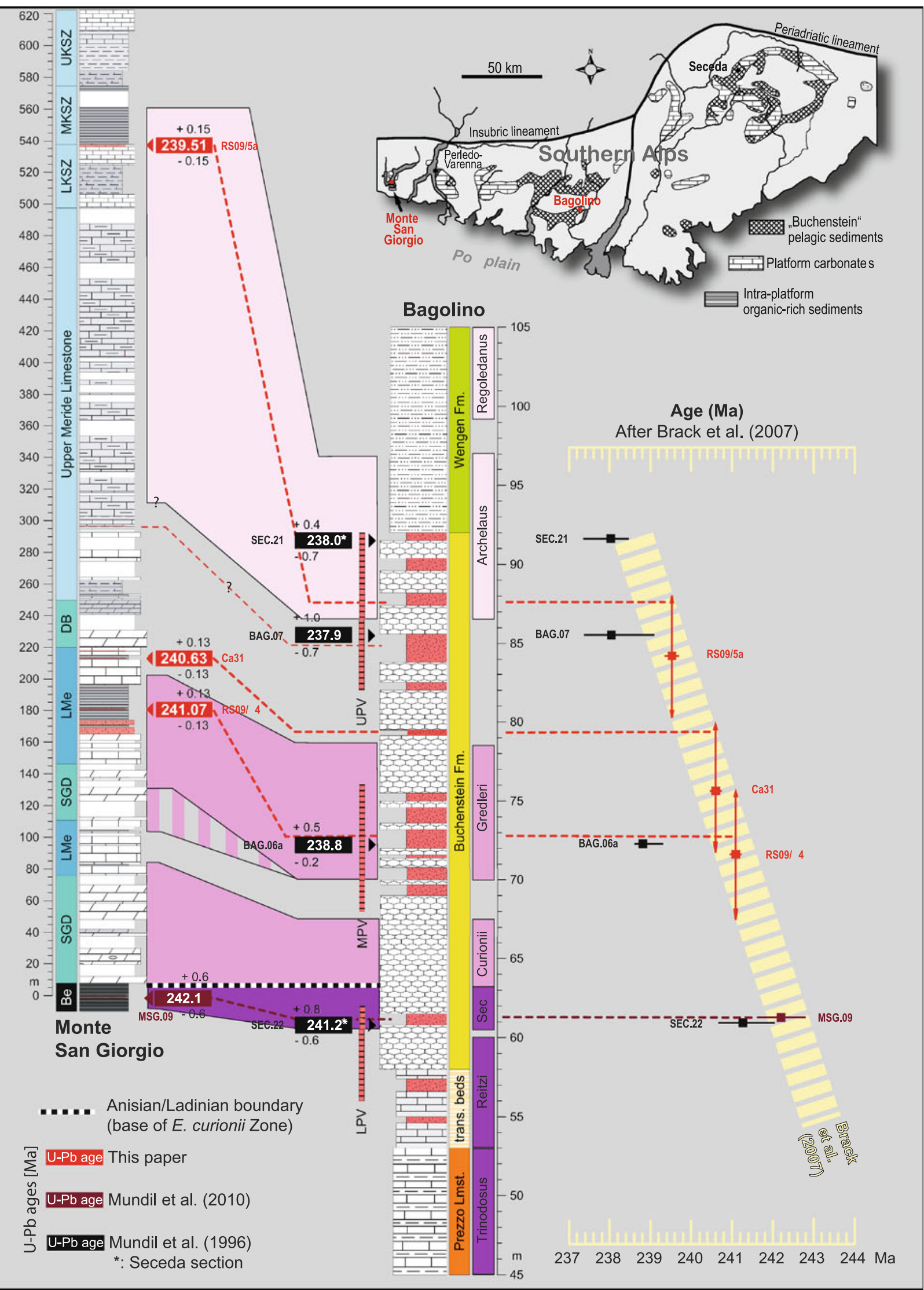


4 Fig. 10 Correlation of the Ladinian composite section at Monte San Giorgio with the GSSP-section at Bagolino. In order to illustrate the proposed lithologic and biostratigraphic correlation, the metric log scales differ by an order of magnitude $(1 \mathrm{~m}$ in the Bagolino section $=10 \mathrm{~m}$ in the Monte San Giorgio section). Earlier U-Pb zircon ages indicated for Bagolino and Seceda are from Mundil et al. (1996; samples BAG and SEC, air-abrasion pre-treatment technique) and for Monte San Giorgio from Mundil et al. (2010; sample MSG, CA pre-treatment technique). See text for a short discussion of the older apparent ages at Seceda and Bagolino. Possible correspondences of volcaniclastic layers are established using the age trend suggested for Bagolino (Brack et al. 2007: fig. 11). On this trend the red squares mark the position of the new radio-isotopic ages. Red arrows indicate the inferable width of the correlatable stratigraphic intervals at Bagolino and the red dotted lines indicate possibly corresponding horizons, also taking into account the biostratigraphic constraints. Important reference localities and the distribution of lower Ladinian units are shown in a sketch map of the Southern Alps (after Brack and Rieber 1993)

sediment-starved Buchenstein facies of the Bagolino section. Sedimentation rates (not decompacted) at Bagolino average $8 \mathrm{~m} / \mathrm{Myr}$ (Brack et al. 2007), a value typical of pelagic sediments. Based on the new radio-isotopic ages, compacted sedimentation rates of the Upper Meride Limestone bracketed by the $240.63 \pm 0.13 \mathrm{Ma}$ (Cassina beds) and $239.51 \pm 0.15 \mathrm{Ma}$ (Lower Kalkschieferzone) $\mathrm{U}-\mathrm{Pb}$ dates can be estimated to be around $290 \mathrm{~m} / \mathrm{Myr}$. The thickness of $182 \mathrm{~m}$ between the U-Pb dates of $242.1 \pm$ 0.6 Ma (middle Besano Formation; Mundil et al. 2010) and $241.07 \pm 0.13 \mathrm{Ma}$ (Cava superiore beds) suggests a sedimentation rate of about $180 \mathrm{~m} / \mathrm{Myr}$. However, as the older age lies within the Besano Formation, which is characterized by very low sedimentation rates $(5-7 \mathrm{~m} / \mathrm{Myr}$; Bernasconi 1994. 1-5 m/Myr; Furrer 1995), the sedimentation rates of the Monte San Giorgio Dolomite and the Lower Meride Limestone can easily exceed $200 \mathrm{~m} / \mathrm{Myr}$ as well. The inferred sedimentation rates exceed by more than 20 times those reported from the Bagolino section (see above) or equivalent Buchenstein-type sections outside the Southern Alps (e.g. Brühwiler et al. 2007). Such values are much closer to the sedimentation rates suggested for the, likely genetically-related, basin of the Perledo-Varenna Formation ( $>100 \mathrm{~m} / \mathrm{Myr}$; Gaetani et al. 1992) where around $400 \mathrm{~m}$ of limestones, mainly from dilute lime mud turbidity currents, were deposited under high subsidence conditions. However, the value is much higher than the sedimentation rate of $80 \mathrm{~m} / \mathrm{Myr}$ suggested by Furrer et al. (2008) for the carbonate platform sediments of the Ladinian Altein Formation at Ducanfurgga (Upper Australpine, Switzerland; Fig. 1b).

Lower sedimentation rates can be inferred for the vertebrate-fossil-bearing interval in the upper part of the Lower Meride Limestone, where the two U-Pb dates of $241.07 \pm 0.13 \mathrm{Ma}$ and $240.63 \pm 0.13 \mathrm{Ma}$ suggest a bulk sedimentation rate of around $70 \mathrm{~m} / \mathrm{Myr}$ for the $32-\mathrm{m}$-thick

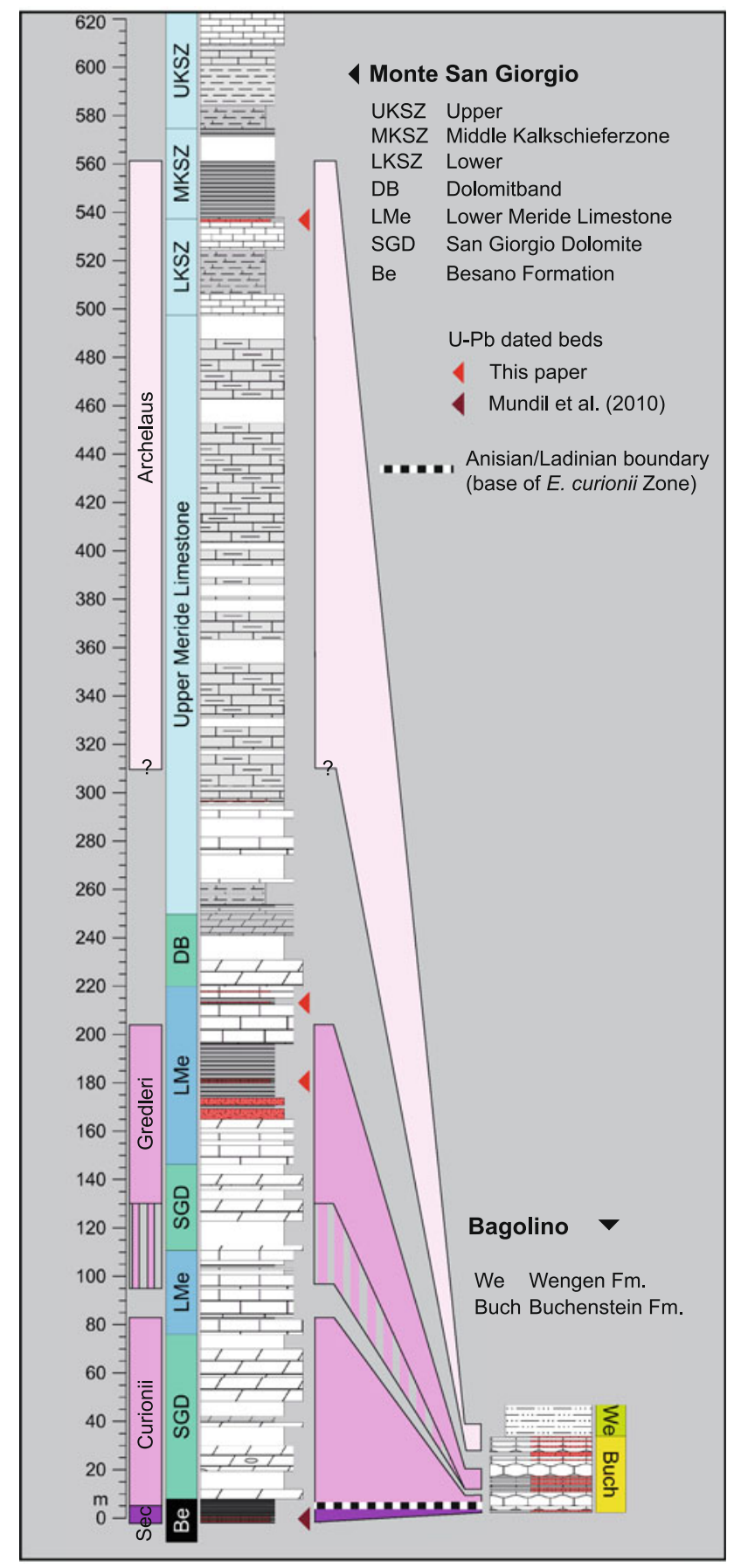

Fig. 11 The illustration of the correlation between Monte San Giorgio and Bagolino at equal metric scales highlights the striking difference in stratigraphic thickness of corresponding intervals

interval (45-178 $\mathrm{m} / \mathrm{Myr}$ within the analytical errors). However, according to the new measurements in the Valle della Cassina section, up to the $56 \%$ of the interval results from short-term sedimentation (lime mud turbidites and volcanic ash layers, corresponding respectively to the turbidite and tephra lithofacies of Stockar 2010), whereas laminated limestones compose the remaining $44 \%$ 
(laminite lithofacies of Stockar 2010). Taking this into account, values of around $32 \mathrm{~m} / \mathrm{Myr}$ more likely match the sedimentation rates of the laminite lithofacies, which represents the background sedimentation (Stockar 2010); within the analytical errors of the U-Pb dating, these values would range between 20 and $78 \mathrm{~m} / \mathrm{Myr}$.

\subsection{Palaeontological implications}

With the new geochronologic and biostratigraphic data, first high-resolution age constraints for the world-famous marine vertebrate faunas of the Meride Limestone are available and the age of the fossil associations is defined to the substage and ammonoid zone level.

The ${ }^{206} \mathrm{~Pb} /{ }^{238} \mathrm{U}$ age of $241.07 \pm 0.13 \mathrm{Ma}$ (sample RS09/4) is assigned to the vertebrate fauna from the lower part of the Cava superiore beds, containing the dated ash layer. Since the fossiliferous interval is around $10 \mathrm{~m}$ thick (mostly extending above, i.e. younger than the dated layer), the fauna of the Cava superiore beds reasonably represents a time interval of about $0.3 \mathrm{Myr}$.

The fauna from the Cava inferiore beds, a fossiliferous interval never exceeding $2 \mathrm{~m}$ in thickness (Furrer 1999a, 2001), is only slightly older than that described above. Without considering the 3-m-thick upper bed of the Val Serrata tuff, resulting from short-term sedimentation, the laminated limestones containing this fauna would lie only $7 \mathrm{~m}$ below the dated sample RS09/4; excluding the event beds (dilute lime turbidites), this gap would further decrease to only $5 \mathrm{~m}$. By taking this into consideration and applying the sedimentation rates discussed above, the age of Cava inferiore beds would be around 241.2 $\pm 0.13 \mathrm{Ma}$.

Both the above faunas are attributed to the late Fassanian $P$. gredleri Amm. Zone on the basis of the biostratigraphic data (Fig. 4).

The ${ }^{206} \mathrm{~Pb} /{ }^{238} \mathrm{U}$ age of $240.63 \pm 0.13 \mathrm{Ma}$ is assigned to the fossil assemblage from the Cassina beds which is ascribed to the transition interval between the $P$. gredleri and the P. archelaus Amm. Zones.

The fossil assemblage from the Lower Kalkschieferzone (Val Mara, Site D) is dated to the ${ }^{206} \mathrm{~Pb} /{ }^{238} \mathrm{U}$ age of $239.51 \pm 0.15 \mathrm{Ma}$ and it is assigned to the early Longobardian (early late Ladinian, P. archelaus Amm. Zone). Accordingly, the age of this assemblage, mainly consisting in actinopterygian fishes, crustaceans and rare insects, is older than previously thought (i.e. latest Ladinian; Tintori and Lombardo 1999; Lombardo et al. 2011).

The new high-resolution U-Pb ages also allow to shed light on the possible correlation between the vertebrate faunas of Monte San Giorgio and those of the upper part of the Prosanto Formation at Ducanfurgga (Upper Austroalpine, Switzerland; Fig. 1b), also including actinopterygian fishes and marine reptiles (Bürgin et al. 1991; Furrer 2004).
Since the latter fauna was $\mathrm{U}-\mathrm{Pb}$ dated to an age of $240.91 \pm 0.26 \mathrm{Ma}$ (Furrer et al. 2008; ID-TIMS with CA pre-treatment technique), a time equivalence of this fauna with those from the Cava superiore/Cava inferiore beds is now inferred. Common elements of the vertebrate assemblages, such as the small fish genera Habroichthys and Placopleurus, particularly suggest analogies between the Cava inferiore beds and the Prosanto Formation; the latter, however, yielded a more diversified fauna, including also rare finds of large fish genera (Birgeria, Colobodus) and a placodont reptile. According to the palaeogeographical reconstruction of Brack et al. (1999), the Prosanto Formation and the Meride Limestone were deposited in restricted basins on the continental shelf of the western Neo-Tethys, which were located relatively close to each other (distance around 100-200 km). The taxic differences between the age-equivalent fossil assemblages of the Meride Limestone and the Prosanto Formation are most likely environment-related or due to a some degree of endemism developed in such intraplatform basins of western Neo-Tethys (e.g. Rieppel 2000).

Based on its attribution to the upper E. curionii Amm. Zone (Lombardo et al. 2008), the fish fauna of the Buchenstein Formation of the Northern Grigna Mountain (Fig. 1b) cannot be correlated with any of the classic vertebrate assemblages of Monte San Giorgio. It is younger than the fauna of the Upper Besano Formation but older than that of the Cava inferiore beds.

Lombardo et al. (2005) suggested an analogy between the fauna from the Cava inferiore beds and that from several, unfortunately not documented, outcrops, located some kilometres to the west and belonging to the lower part of the Cunardo Formation (northern Italy, Varese Province). If confirmed, the latter fauna would belong to the late Fassanian P. gredleri Amm. Zone as well.

\section{Conclusions}

The newly defined biostratigraphic and geochronologic constraints for the Ladinian sequence of Monte San Giorgio allow to resolve to the zone level the age of the classic fossil-bearing horizons of the Meride Limestone, which are assigned to the $P$. gredleri Amm. Zone (late Fassanian: Cava inferiore beds and Cava superiore beds), to the transition interval between the $P$. gredleri and the $P$. archelaus Amm. Zones (Cassina beds) and to the P. archelaus Amm. Zone (early Longobardian: Site D of the Lower Kalkschieferzone). These horizons are shown to correlate with the main volcaniclastic intervals of the Buchenstein Formation (Middle and Upper Pietra Verde). The new results show that the $600 \mathrm{~m}$ thick Ladinian section encompasses a time interval of around $3 \mathrm{Myr}(242-239 \mathrm{Ma})$. If also the 
lower (Illyrian) part of the Besano Formation is taken into account and by using the U-Pb date of $242.8 \pm 0.2 \mathrm{Ma}$ yielded by CA-treated zircons from the uppermost $R$. reitzi Amm. Zone in the Latemar platform (Dolomites; Brack et al. 2007), the time interval encompassed by the whole vertebrate-fossil-bearing section of Monte San Giorgio increases to around $4 \mathrm{Myr}$ (243-239 Ma). This time interval is much shorter than that so far reported (10-15 Myr; e.g. Tintori and Lombardo 2005; Tintori 2011); accordingly, evolutionary rates inferable from the different faunal associations replacing each other throughout the section are much higher.

The new high-resolution U-Pb dates confirm (see also discussion in Brack et al. 2007) that available ages from Bagolino (GSSP for the base of the Ladinian) and Seceda (the principal auxiliary section in the Dolomites) are too young (by around $2 \mathrm{Myr}$ ) and that a shift towards older ages should be expected by using pre-treatment techniques more effective in eliminating $\mathrm{Pb}$ loss. They also support the reliability of the extrapolated age trend obtained by Brack et al. (2007) for the Bagolino section. Coupled with highresolution single-zircon U-Pb CA-TIMS dating, the graph of Brack et al. (2007) proves a powerful correlation tool for this time interval.

The detailed re-measurement of the entire section and the new geochronologic constraints allow the sedimentation rates to be assessed. Bulk sedimentation rates exceeding $200 \mathrm{~m} / \mathrm{Myr}$ are representative for the San Giorgio Dolomite and the Meride Limestone (at least up to the Lower Kalkschieferzone), mainly composed of reworked carbonate mud stirred up from the surrounding platforms. Sedimentation rates decrease by an order of magnitude (to around $30 \mathrm{~m} / \mathrm{Myr}$ ) in the intervals composed by laminated limestones, which host the classic fossilvertebrate assemblages of the Lower Meride Limestone. The inferred average sedimentation rates are by more than an order of magnitude higher if compared to those reported from the (sediment-starved) pelagic Buchenstein facies of the Southern Alps and its equivalents of the western NeoTethys. Such high values are ascribed to the high carbonate productivity of the adjoining platforms and to a high, likely tectonically-controlled, subsidence. Finally, the new biostratigraphic and geochronologic data allow a better comparison of the Ladinian vertebrate assemblages of Monte San Giorgio with other similar faunas from the South-Alpine and Austroalpine realms.

Acknowledgments We are grateful to Hans Rieber (Zürich) for the identification of the ammonoids. The first author is indebted to Evelyn Kustatscher (Bozen) and David Bodman (Sheffield) for the stimulating discussions about palynological aspects, to Paulian Dumitrica (IGP, UNI Lausanne) for the revision of the determination of the radiolarian specimens illustrated herein and especially to Daniel Bernoulli (UNI Basel) for comments on an earlier version of the manuscript. Thierry
Adatte (IGP, UNI Lausanne) kindly performed the mineralogical analyses of the bentonite samples. SEM work considerably benefited from technical assistance of Pierre Vonlanthen (IGP, UNI Lausanne). We particularly acknowledge Neria Römer who assisted during all the first author's field work. Sergio Pezzoli (Milano), Sergio Rampinelli (Bergamo), Lara Lucini (MCSN) and Medea Proce (UNI Basel) kindly provided assistance in the field and in the fossil preparation. $\mathrm{U}-\mathrm{Pb}$ radio-isotopic dating at NERC Isotope Geosciences Laboratory (NIGL), British Geological Survey, Nottingham, UK, and palynological preparations at MB Stratigraphy, Sheffield, UK, were granted by the Dipartimento del territorio del Cantone Ticino (Museo Cantonale di Storia Naturale) and the Swiss Federal Office for the Environment. This paper greatly benefited from constructive comments by Heinz Furrer (PIMUZ) and Urs Schaltegger (UNI Genève) and especially from a very careful review by Peter Brack (ETH Zürich) which greatly contributed to improve the manuscript. Peter Hochuli kindly checked the palynological part of the paper.

\section{References}

Bernasconi, S. M. (1994). Geochemical and microbial controls on dolomite formation in anoxic environments: A case study from the Middle Triassic (Ticino, Switzerland). Contributions to Sedimentology, 19, 1-109.

Bernoulli, D. (2007). The pre-Alpine geodynamic evolution of the Southern Alps: A short summary. Bulletin für Angewandte Geologie, 12(2), 3-10.

Bernoulli, D., Govi, M., Graeter, P., Lehner, P., Reinhard, M., \& Spicher, A. (1976). Geologischer Atlas der Schweiz 1:25000, Blatt 1353 Lugano (Atlasblatt 69). Schweizerische geologische Kommission.

Bertotti, G., Picotti, V., Bernoulli, D., \& Castellarin, A. (1993). From rifting to drifting: Tectonic evolution of the South-Alpine upper crust from the Triassic to the Early Cretaceous. Sedimentary Geology, 86, 53-76.

Brack, P., \& Muttoni, G. (2000). High-resolution magnetostratigraphic and lithostratigraphic correlations in Middle Triassic pelagic carbonates from the Dolomites (northern Italy). Palaeogeography, Palaeoclimatology, Palaeoecology, 161, 361-380.

Brack, P., \& Rieber, H. (1993). Towards a better definition of the Anisian/Ladinian boundary: New biostratigraphic data and correlations of boundary sections from the Southern Alps. Eclogae Geologicae Helvetiae, 86, 415-527.

Brack, P., Rieber, H., \& Urlichs, M. (1999). Pelagic successions in the Southern Alps and their correlation with the Germanic Middle Triassic. In: G. H. Bachmann \& I. Lerche (Eds.), Epicontinental Triassic. Zentralblatt für Geologie und Paläontologie (1998) Teil 1 (pp. 853-876). Stuttgart: E. Schweizerbart'sche Verlagsbuchhandlung.

Brack, P., Schlager, W., Stefani, M., Maurer, F., \& Kenter, J. (2000). The Seceda Drill Hole in the Middle Triassic Buchenstein beds (Livinnalongo Formation, Dolomites, Northern Italy), A progress report. Rivista Italiana di Paleontologia e Stratigrafia, 106, 283-292.

Brack, P., Rieber, H., Nicora, A., \& Mundil, R. (2005). The Global boundary Stratotype Section and Point (GSSP) of the Ladinian Stage (Middle Triassic) at Bagolino (Southern Alps, Northern Italy) and its implications for the Triassic time scale. Episodes, 28, 233-244.

Brack, P., Rieber, H., Mundil, R., Blendinger, W., \& Maurer, F. (2007). Geometry and chronology of growth and drowning of Middle Triassic carbonate platforms (Cernera and Bivera/ Clapsavon) in the Southern Alps (northern Italy). Swiss Journal of Geosciences, 100, 327-348. 
Brugman, W. A. (1986). A palynological characterization of the Upper Scythian and Anisian of the Transdanubian Range (Hungary) and the Vicentinian Alps (Italy). PhD dissertation. State University of Utrecht, Utrecht, The Netherlands, 95 pp.

Brühwiler, T., Hochuli, P. A., Mundil, R., Schatz, W., \& Brack, P. (2007). Bio- and chronostratigraphy of the Middle Triassic Reifling Formation in the westernmost Northern Calcareous Alps. Swiss Journal of Geosciences, 100, 443-455.

Bürgin, T. (1995). Actinopterygian fishes (Osteichthyes; Actinopterygii) from the Kalkschieferzone (Uppermost Ladinian) near Meride (Canton Ticino, Southern Switzerland). Eclogae Geologicae Helvetiae, 88, 803-826.

Bürgin, T. (1999). Middle Triassic marine fish faunas from Switzerland. In G. Arratia \& H.-P. Schultze (Eds.): Mesozoic Fishes 2 - Systematics and Fossil Record (pp. 481-494). München: Pfeil.

Bürgin, T., Rieppel, O., Sander, P. M., \& Tschanz, K. (1989). The fossils of Monte San Giorgio. Scientific American, 260, 74-81.

Bürgin, T., Eichenberger, U., Furrer, H., \& Tschanz, K. (1991). Die Prosanto-Formation-eine fischreiche Fossil-Lagerstätte in der Mitteltrias der Silvretta-Decke (Kanton Graubünden, Schweiz). Eclogae Geologicae Helvetiae, 84, 921-990.

Caby, R., \& Galli, J. (1964). Existence de cinérites et de tufs volcaniques dans le Trias moyen de la zone briançonnaise. Comptes rendus de l'Académie des Sciences, 259, 417-420.

Calabrese, L., \& Balini, M. (1995). The discovery of ammonoids in the Cunardo Formation (Varese). A new chronostratigraphic interpretation. Rivista Italiana di Paleontologia e Stratigrafia, 101, 367-370.

Cirilli, S. (2010). Upper Triassic-lowermost Jurassic palynology and palynostratigraphy: A review. In S.G. Lucas (Ed.), The Triassic Timescale (pp. 285-314). Special Publications of the Geological Society of London, 334.

Condon, D., Schoene, B., Bowring, S., Parrish, R., McLean, N., Noble, S., \& Crowley, Q. (2007). EARTHTIME; isotopic tracers and optimized solutions for high-precision U-Pb ID-TIMS geochronology. Eos Transactions American Geophysical Union, 88(52), Fall Meeting Supplement, Abstract V41E-06.

Crowley, J. L., Schoene, B., \& Bowring, S. A. (2007). U-Pb dating of zircon in the Bishop Tuff at the millennial scale. Geology, 35, $1123-1126$.

Etter, W. (2002). Monte San Giorgio: Remarkable Triassic Marine Vertebrates. In D. J. Bottjer et al. (Eds.), Exceptional fossil preservation. A unique view on the evolution of marine life (pp. 220-242). New York: Columbia University Press.

Forster, S. C., \& Warrington, G. (1985). Geochronology of the Carboniferous, Permian and Triassic. In N. J. Snelling (Ed.), The Chronology of the Geological Record (pp. 77-117). Oxford, Blackwell Scientifics: Geological Society Memoir.

Frauenfelder, A. (1916). Beiträge zur Geologie der Tessiner Kalkalpen. Eclogae Geologicae Helvetiae, 14, 247-367.

Furrer, H. (1995). The Kalkschieferzone (Upper Meride Limestone; Ladinian) near Meride (Canton Ticino, Southern Switzerland) and the evolution of a Middle Triassic intraplatform basin. Eclogae Geologicae Helvetiae, 88, 827-852.

Furrer, H. (1999a). Aktuelle Grabungen in den Unteren MerideKalken bei Acqua del Ghiffo. In Zoologisches Museum der Universität Zürich (Ed.), Fossilien und ihre Forschung in Geschichte und Gegenwart (pp. 87-103). Zürich: Zoologisches Museum der Universität Zürich.

Furrer, H. (1999b). New excavations in marine Middle Triassic Fossil-Lagerstätten at Monte San Giorgio (Canton Ticino, Southern Switzerland) and the Duncan Mountains near Davos (Canton Graubünden, Eastern Switzerland). In S. Renesto (Ed.), Third International Symposium on Lithographic Limestones (pp. 85-88). Bergamo: Museo Civico di Scienze naturali "Enrico Caffi".
Furrer, H. (2001). Fossil-Lagerstätten in the Lower Meride Limestone, Ladinian. International Meeting on Mesozoic Fishes 3-Systematics, Paleoenvironments and Biodiversity, Serpiano. Guide book to the field trip to Acqua del Ghiffo near Crocifisso, Meride TI, pp. 1-11.

Furrer, H. (2003). Der Monte San Giorgio im Südtessin—Vom Berg der Saurier zur Fossil-Lagerstätte internationaler Bedeutung. Neujahrsblatt der Naturforschenden Gesellschaft Zürich, 206, 1-64.

Furrer, H. (2004). So kam der Fish auf den Berg-Eine Broschüre zur Sonderausstellung über die Fossilfunde am Ducan (32 pp). Chur: Bündner Natur-Museum Chur und Paläontologisches Institut und Museum der Universität Zürich.

Furrer, H., Schaltegger, U., Ovtcharova, M., \& Meister, P. (2008). $\mathrm{U}-\mathrm{Pb}$ zircon age of volcaniclastic layers in Middle Triassic platform carbonates of the Austroalpine Silvretta nappe (Switzerland). Swiss Journal of Geosciences, 101, 595-603.

Gaetani, M., Gnaccolini, M., Poliani, G., Grignani, D., Gorza, M., \& Martellini, L. (1992). An anoxic intraplatform basin in the Middle Triassic of Lombardy (Southern Alps, Italy): Anatomy of a hydrocarbon source. Rivista Italiana di Paleontologia $e$ Stratigrafia, 97, 329-354.

Gianolla, P., De Zanche, V., \& Mietto, P. (1998). Triassic sequence stratigraphy in the Southern Alps (Northern Italy): Definition of sequences and basin evolution. In P.-C. De Graciansky et al. (Eds), Mesozoic and Cenozoic sequence stratigraphy of European Basins (pp. 719-747). Special Publications 60. Tulsa: SEPM (Society for Sedimentary Geology).

Gianotti, R., \& Tannoia, G. (1988). Elementi per una revisione stratigrafico-paleontologica del Trias medio superiore della regione compresa tra il Lario e il Ceresio. Atti Ticinensi di Scienze della Terra, 31, 434-445.

Gradstein, F. M., Agterberg, F. P., Ogg, J. G., Hardenbol, J., Van Veen, P., Thierry, J., et al. (1994). A Mesozoic time scale. Journal of Geophysical Research, B, Solid Earth and Planets, 99, 24051-24074.

Gradstein, F. M., Ogg, J., \& Smith, A. (2004). A Geological Time Scale 2004 (589 pp.). Cambridge: Cambridge University Press.

Hänni, K. (2004). Die Gattung Ceresiosaurus. Ceresiosaurus calcagnii Peyer und Ceresiosaurus lanzi n. sp. (Lauriosauridae, Sauropterygia) (147 pp.). Zürich: Vdf Hochschulverlag ETH Zürich.

Hellmann, K. N., \& Lippolt, H. J. (1981). Calibration of the Middle Triassic Time Scale by conventional $\mathrm{K}-\mathrm{Ar}$ and ${ }^{40} \mathrm{Ar} /{ }^{39} \mathrm{Ar}$ dating of alkali feldspars. Journal of Geophysics, 50, 73-88.

Hochuli, P. A., \& Roghi, G. (2002). A palynological view on the Anisian/Ladinian boundary-new results from the Seceda section (Dolomites, Northern Italy). I.U.G.S. Commission on Triassic Stratigraphy, STS/IGCP, Field Meeting (pp. 29-30). Veszpröm: Program \& Abstracts.

Jaffey, A. H., Flynn, K. F., Glendenin, L. E., Bentley, W. C., \& Essling, A. M. (1971). Precision measurement of half-lives and specific of ${ }^{235} \mathrm{U}$ and ${ }^{238} \mathrm{U}$. Physics Reviews, C4, 1889-1906.

Kozur, H. W. (2003). Integrated ammonoid, conodont and radiolarian zonation of the Triassic and some remarks to Stage/Substage subdivision and the numeric age of the Triassic stages. Albertiana, 28, 57-74.

Krzeminski, W., \& Lombardo, C. (2001). New fossil Ephemeroptera and Coleoptera from the Ladinian (Middle Triassic) of Canton Ticino (Switzerland). Rivista Italiana di Paleontologia e Stratigrafia, 107, 69-78.

Kuhn-Schnyder, E. (1974). Die Triasfauna der Tessiner Kalkalpen. Neujahrsblatt der Naturforschenden Gesellschaft Zürich, 176, $1-119$.

Kuhn-Schnyder, E., \& Vonderschmitt, L. (1954). Geologische und paläontologische Probleme des Südtessins. Eclogae Geologicae Helvetiae, 46(2), 223-236. 
Lombardo, C. (2002). Caelatichthys gen. n.: A new palaeonisciform from the Middle Triassic of Northern Italy and Canton Ticino (Switzerland). Rivista Italiana di Paleontologia e Stratigrafia, 108, 399-414.

Lombardo, C., \& Tintori, A. (2004). New Perleidiforms from the Triassic of the Southern Alps and the revision of Serrolepis from the Triassic of Wüttemberg (Germany). In G. Arratia \& A. Tintori (Eds.), Mesozoic Fishes 3-systematics, paleoenvironments and biodiversity (pp. 179-196). München: Pfeil.

Lombardo, C., Renesto, S., \& Tintori, A. (2005). Primi vertebrati fossili dalla Formazione di Cunardo (Ladinico inferiore, Triassico Medio) della Valtravaglia (Varese). Geologia Insubrica, $8(2), 5-9$.

Lombardo, C., Rusconi, M., \& Tintori, A. (2008). New perleidiform from the lower Ladinian (Middle Triassic) of the Northern Grigna (Northern Italy). Rivista Italiana di Paleontologia $e$ Stratigrafia, 114, 263-272.

Lombardo, C., Sun, Z. Y., Tintori, A., Jiang, D. Y., \& Hao, W. C. (2011). A new species of the genus Perleidus (Actinopterygii:Perleidiformes) from the Middle Triassic of Southern China. Bollettino della Società Paleontologica Italiana, 50(2), $75-83$.

Ludwig, K. R. (1991). Isoplot—a plotting and regression program for radiogenic isotope data: USGS Open File Report, pp. 91-445.

Mattinson, J. M. (2005). Zircon U-Pb chemical abrasion ("CATIMS") method: Combined annealing and multistep partial dissolution analyses for improved precision and accuracy of zircon ages. Chemical Geology, 220, 47-66.

McRoberts, C. A. (2010). Biochronology of Triassic bivalves. In S.G. Lucas (Ed.) The Triassic Timescale (pp. 201-219). Special Publications of the Geological Society of London, 334.

Mietto, P., \& Manfrin, S. (1995). A high resolution Middle Triassic ammonoid standard scale in the Tethys Realm; a preliminary report. Bulletin de la Société geologiqué de France, 166, 539-563.

Mietto, P., Manfrin, S., Preto, N., Gianolla, P., Krystyn, L., \& Roghi, G. (2003). Proposal of the global stratigraphic section and point (GSSP) for the base of the Ladinian Stage (Middle Triassic). GSSP at the base of the Avisianum Subzone (FAD of Aplococeras avisianum) in the Bagolino section (Southern Alps, NE Italy). Albertiana, 28, 26-34.

Müller, W., Schmid, R., \& Vogt, P. (1964). Vulcanogene Lagen aus der Grenzbitumenzone (Mittlere Trias) des Monte San Giorgio in den Tessiner Kalkalpen. Eclogae Geologicae Helvetiae, 57, 431-450.

Mundil, R., Brack, P., Meier, M., Rieber, H., \& Oberli, F. (1996). High resolution $\mathrm{U}-\mathrm{Pb}$ dating of Middle Triassic volcaniclastics: time-scale calibration and verification of tuning parameters for carbonate sedimentation. Earth and Planetary Science Letters, 141, 137-151.

Mundil, R., Pálfy, J., Renne, P. R., \& Brack, P. (2010). The Triassic timescale: New constraints and a review of geochronological data. In S.G. Lucas (Ed.) The Triassic Timescale (pp. 41-60). Special Publications of the Geological Society of London, 334.

Muttoni, G., Nicora, A., Brack, P., \& Kent, D. V. (2004). Integrated Anisian-Ladinian boundary chronology. Palaeogeography, Palaeoclimatology, Palaeoecology, 208, 85-102.

Pálfy, J., Parrish, R. R., David, K., \& Vörös, A. (2003). Mid-Triassic integrated $\mathrm{U}-\mathrm{Pb}$ geochronology and ammonoid biochronology from the Balaton Highland (Hungary). Journal of the Geological Society (London), 160, 271-284.

Peyer, B. (1931). Ceresiosaurus calcagnii nov. gen. nov. spec. Abhandlungen der Schweizerischen Paläontologischen Gesellschaft, 62, 1-87.

Picotti, V., Capozzi, R., Bertozzi, G., Mosca, F., Sitta, A., \& Tornaghi, M. (2007). The Miocene petroleum system of the
Northern Apennines in the central Po Plain (Italy). In O. Lacombe et al. (Eds), Thrust belts and foreland basins. From fold kinematics to hydrocarbon systems (pp. 117-131). Heidelberg: Springer.

Rieber, H. (1969). Daonellen aus der Grenzbitumenzone der mittleren Trias des Monte San Giorgio (Kt. Tessin, Schweiz). Eclogae Geologicae Helvetiae, 62, 657-683.

Rieber, H. (1973a). Ergebnisse paläontologish-stratigraphischer Untersuchungen in der Grenzbitumenzone (Mittlere Trias) des Monte San Giorgio (Kanton Tessin, Schweiz). Eclogae Geologicae Helvetiae, 66, 667-685.

Rieber, H. (1973b). Cephalopoden aus der Grenzbitumenzone (Mittlere Trias) des Monte San Giorgio (Kanton Tessin, Schweiz). Schweizerische Paläontologische Abhandlungen, 93, 1-96.

Rieppel, O. (1985). Die Triasfauna der Tessiner Kalkalpen XXV. Die Gattung Saurichthys (Pisces, Actinopterygii) aus der mittleren Trias des Monte San Giorgio, Kanton Tessin. Schweizerische Paläontologische Abhandlungen, 108, 1-103.

Rieppel, O. (2000). Sauropterygia I. Placodontia, Pachypleurosauria, Nothosauroidea, Pistosauroidea. In P. Wellnhofer (Ed.), Handbuch der Paläoherpetologie/Encyclopedia of Paleoherpetology, Teil 12A (pp. 1-134). München: Pfeil.

Roghi, G. (1995). Indagine palinologica del Trias medio del Sudalpino. PhD dissertation. Università di Padova, Padova, Italy, $121 \mathrm{pp}$.

Roghi, G. (1997). Indagini palinologiche nella sezione della Val Gola (Trento). Studi Trentini di Scienze Naturali. Acta Geologica, 71(1994), 91-105.

Röhl, H. J., Schmid-Röhl, A., Furrer, H., Frimmel, A., Oschmann, W., \& Schwark, L. (2001). Microfacies, geochemistry and palaeoecology of the Middle Triassic Grenzbitumenzone from Monte San Giorgio (Canton Ticino, Switzerland). Geologia Insubrica, 6(1), 1-13.

Sander, M. P. (1989). The pachypleurosaurids (Reptilia: Nothosauria) from the Middle Triassic of Monte San Giorgio (Switzerland) with the description of a new species. Philosophical transactions of the Royal Society of London B, 325, 561-670.

Schatz, W. (2001). Taxonomic significance of biometric characters and the consequences for classification and biostratigraphy, exemplified through moussoneliform daonellas (Daonella, Bivalvia; Triassic). Paläontologische Zeitschrift, 75, 51-70.

Schatz, W. (2005). Taxonomie, Paläoökologie und biostratigraphische Anwendung der Daonellen (Bivalvia, Mollusca) aus der Mitteltrias Europas. Schweizerische Paläontologische Abhandlungen, 125, 1-177.

Scheuring, B. W. (1978). Mikrofloren aus den Meridekalken des Mte. San Giorgio (Kanton Tessin). Schweizerische Paläontologische Abhandlungen, 100, 1-205.

Scheyer, T. M., Neenan, J. M., Renesto, S., Saller, F., Hagdorn, H., Furrer, H., et al. (2011). Revised paleoecology of placodontswith a comment on 'The shallow marine placodont Cyamodus of the central European Germanic Basin: Its evolution, paleobiogeography and paleoecology' by C.G. Diedrich (Historical Biology, iFirst article, 2011, 1-19, doi:10.1080/08912963.2011. 575938). Historical Biology,. doi:10.1080/08912963.2011.62 1083.

Schmitz, M. D., \& Schoene, B. (2007). Derivation of isotope ratios, errors, and error correlations for U-Pb geochronology using $\mathrm{Pb}-205-\mathrm{U}-235-(\mathrm{U}-233)$-spiked isotope dilution thermal ionization mass spectrometric data. Geochemistry Geophysics Geosystems (G3) 8(8), Q08006, doi:10.1029/2006GC001492.

Senn, A. (1924). Beiträge zur Geologie des Alpensüdrandes zwischen Mendrisio und Varese. Eclogae Geologicae Helvetiae, 18, 552-632.

Sommaruga, A., Hochuli, P. A., \& Mosar, J. (1997). The Middle Triassic (Anisian) conglomerates from Capo San Martino, South 
of Lugano-Paradiso (Southern Alps, Switzerland). Geologia Insubrica, 2(1), 1-14.

Stampfli, G. M., \& Borel, G. D. (2002). A plate tectonic model for the Paleozoic and Mesozoic constrained by dynamic plate boundaries and restored synthetic oceanic isochrons. Earth and Planetary Science Letters, 196, 17-33.

Steiger, R. H., \& Jäger, E. (1977). Subcommission on geochronology-convention on use of decay constants in geochronology and cosmochronology. Earth and Planetary Science Letters, 36, 359-362.

Stockar, R. (2010). Facies, depositional environment, and palaeoecology of the Middle Triassic Cassina beds (Meride Limestone, Monte San Giorgio, Switzerland). Swiss Journal of Geosciences, 103, 101-119.

Stockar, R., \& Kustatscher, E. (2010). The Ladinian flora from the Cassina beds (Meride Limestone, Monte San Giorgio, Switzerland): Preliminary results. Rivista Italiana di Paleontologia e Stratigrafia, 116, 173-188.

Stockar, R., \& Renesto, S. (2011). Co-occurrence of Neusticosaurus edwardsii and $N$. peyeri (Reptilia) in the Lower Meride Limestone (Middle Triassic, Monte San Giorgio). Swiss Journal of Geosciences, 104(suppl. 1), 167-178.

Tintori, A. (2011). Comment on "The vertebrates of the Anisian/ Ladinian boundary (Middle Triassic) from Bissendorf (NW germany) and their contribution to the anatomy, palaeoecology, and palaeobiogeography of the Germanic Basin reptiles" by C. Diedrich [Palaeogeography, Palaeoclimatology, Palaeoecology 273 (2009) 1-16]. Palaeogeography, Palaeoclimatology, Palaeoecology, 300, 205-207.
Tintori, A., \& Lombardo, C. (1999). Late Ladinian fish faunas from Lombardy (North Italy): Stratigraphy and paleobiology. In G. Arratia \& H.-P. Schultze (Eds.), Mesozoic Fishes 2-systematics and fossil record (pp. 495-504). München: Pfeil.

Tintori, A., \& Lombardo, C. (2005). Middle Triassic fishes from northern Italy. Geoitalia 2005, Epitome, 1, p. 277.

Tintori, A., \& Lombardo, C. (2007). A new early Semionotidae (Semionotiformes, Actinopterygii) from the Upper Ladinian of Monte San Giorgio area (Southern Switzerland and Northern Italy). Rivista Italiana di Paleontologia e Stratigrafia, 113, 369-381.

Traverse, A. (2007). Paleopalynology (813 pp.). Dordrecht: Springer. Van der Eem, J. G. L. A. (1983). Aspects of Middle and Late Triassic Palynology: 6. Palynological investigations in the Ladinian and Lower Karnian of the Western Dolomites, Italy. Review of Palaeobotany and Palynology, 39, 189-300.

Wendt, I., \& Carl, C. (1991). The statistical distribution of the mean squared weighted deviation. Chemical Geology: Isotope Geoscience Section, 86, 275-285.

Wirz, A. (1945). Die Triasfauna der Tessiner Kalkalpen. XV. Beiträge zur Kenntnis des Ladinikums im Gebiete des Monte San Giorgio. Schweizerische Paläontologische Abhandlungen, $65,1-84$.

Zorn, H. (1971). Paläontologische, stratigraphische und sedimentologische Untersuchungen des Salvatoredolomits (Mitteltrias) der Tessiner Kalkalpen. Schweizerische Paläontologische Abhandlungen, 91, 1-90. 